\title{
PATRYSTYKA W CZASOPISMACH 2003 ROKU
}

1. ACTA ORIENTALIA 56 (2003) nr 1-4:

(Nr 1) R. Simon - Natural history of sin. Remarks on the origins of sin in Judaism, Christianity, and Islam 1-34.

2. ACTA UNIVERSITATIS WRATISLAVIENSIS. HISTORIA (2003) nr 160: W. Suder - „Census populi”. Demografia starożytnego Rzymu 1-299.

3. ADAMANTIUS 9 (2003):

Riflessione teologica e pragmatiche sociali in Clemente Alessandrino, a cura di M. Rizzi (M. Rizzi - Introduzione 8-9; L. Lugaresi - „Fuggiamo la consuetudine”: pratiche sociali cristiane, rappresentazione e spettacoli in Clemente Alessandrino 10-18; A. Monaci Castagno - L'arte sottile della distinzione: il «Pedagogo» di Clemente Alessandrino 29-37; V. Neri - Valori estetici e valori etici dell'apparenza del corpo nel "Pedagogo» di Clemente Alessandrino. Alle origini dell'etica cris-

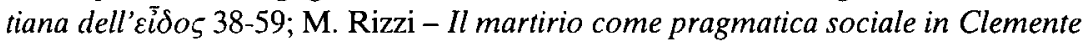
Alessandrino 60-66); S. Badilita - La Communauté des Thérapeutes: une Philonopolis? 67-77; A.L. Jacobsen - Logos - Physician and Teacher: Christology and Soteriology in "Contra Celsum» 78-93; C. Noce - Melchisedech era un angelo? Un riesame dell'accusa di Gerolamo a Origene 94-100; M.B. Zorzi - La reinterpretazione dell'eros platonico nel "Simposio" di Metodio di Olimpo 101-127; H. Buchinger - Zur Nachwirkung der Paschatheologie des Origenes: Sondierungen in der lateinischen Paschahomiletik bis zu Gregor dem Großen 128-169; A. Jakab - Chronique alexandrine II, 170-178; G. Dorival - Hommage à Dominique Barthélemy: des Pères à la Septante 179-187; J.P. Martin - Filone di Alessandria e la letteratura cristiana antica 188-192; M. Simonetti - Un recente libro su Eracleone 193-108; D. Pazzini - Origeniana: Dieci anni di studi e ricerche 209-229; J.P. Martin - Ricerche sulla tradizione alessandrina in Argentina (19832000) $230-250$.

4. AEVUM 77 (2003) nr 1-3:

(Nr 1) M. Sordi - La svolta del II sec. d.C. e la nascita del concetto ecclesiale di 'martire' 27-33; I. Ramelli - Cristiani e vita politica: il cripto-cristianesimo nelle classi dirigenti romane nel II secolo 35-51; C. Martínez-Maza - Devotas mistéricas en la Roma Bajoimperial, 53-68; M. Raimondi - La lotta all'abigeato (CTh IX 30) e alla violazione di tombe nel tardo Impero Romano, 69-83; G. Viansino - Note 
testuali ad Ammiano Marcellino e spunti di esegesi 85-104; R. Sgarbi - Trasferimento interlinguistico di classi grammaticali nell'adattamento armeno dell'ars greca di Dionisio Trace 119-126; A. Scala - Armeno el"ewr 'corno': una proposita etimologica 127-129; R. Sgarbi - Contributi dalla versione armena al testo Filoneo "Peri biou theoretikou" 131-136; A. Pontani - Note sull'esegesi e l'iconografia del „titulus crucis” 137-185; (nr 2) G. Murano - Un „ordo romanus" di provenienza vallombrosana (Firenze, Bibl. nazionale centrale, Conv. Soppr. B. II. 406), 249-262; C.M. Mazzucchi - „Ambrosianus" C 222 inf. (graecus 886): il codice e il suo autore 263-275.

5. ALPHA OMEGA 5 (2003) nr 1-2:

F. Pascual - Comunicación y lenguaje en el «De magistro» de san Agustín 37-57; C. dell'Osso - L'analogia antropologica. Riflessioni sui concetti di anima e corpo in alcuni testi patristici $215-232$

6. THE AMERICAN BENEDICTINE REVIEW 54 (2003) nr 1-4:

$\mathrm{R}$. Cristiani - The Semantic Range of Medical Language in the "Rule» of Benedict 20-29; M. Del Cogliano - Porcarius of Lérins and his "Counsels»: A Monastic Study II, 30-58; J.E. Lawyer - Longing and Loss in the Life of St. Benedict according to Gregory the Great 72-95; C.J. Peifer - Historical Reflections of the Life-Span of Monasteries 121-141; T.G. Kardong - "The Rule of the Four Fathers»: A New English Translation and Commentary 142-180; I. Sutto - Contemplative Experience in Cassian and in the "Rule» of Benedict 181-204; M. Beyer Moser - Becoming the Feast We Offer: Food Sacrifice in Origen's «Homilies on Leviticus» 291-311; G.E. Demacopoulos - The Soteriology of Pope Gregory I: A Case against the Augustinian Interpretation 312-327; A. Nugent - Benedict's Easter 375-383; A. Böckmann-Summoning the Brothers for Counsel (RB3), part I, 384-413; J.K. Newman - Gyrovagues in Dante and St. Benedict 414-419; C.J.N. de Paulo - Whether Intellectuals Pray? Revisiting the Benedictine Tradition, 420435.

7. AMERICAN CATHOLIC PHILOSOPHICAL QUARTERLY 77 (2003) nr 1-4: A.A. Pang-White - Augustine, "akrasia” and Manichaeism 151-169; C.J.N. de Paulo - The Augustinian Constitution of Heidegger's "Being and Time" 549-568.

8. AMERICAN JOURNAL OF PHILOLOGY 124 (2003) nr 1-4:

B.F. McManus - C.A. Rubino - Classics and Internet Technology 601-608.

9. ANÁ MNESIS 13 (2003) nr 1-2:

(Nr 1) F. Soto-Hay - Textos sobre los ritos de iniciación en algunos escritos gnósticos 5-28; (nr 2) F. Soto-Hay - La presencia real de Cristo y la Creación de la Eucaristía 63-88.

10. ANALECTA BOLLANDIANA 121 (2003) nr 1-2:

R.W. Burgess - The "Passio s. Artemii", Philostorgius, and the Dates of the Invention and Translations of the Relics of Sts Andrew and Luke 5-36; X. Lcoqueux - La plus ancienne traduction latine (BHL 41Ob) des Actes grecs du martyr Anastase le Perse. L'œuvre d'un interprète grec? 37-44; B. Joassart - Henri Leclercq et les Bollandistes. Querelle autour des „Martyrs" 108-136; R. Gounclle - Une légende apocryphe relatant la rencontre du bon larron et de la Sainte 
Famille en Égypte (BHG 2119y) 241-272; F. Dolbeau - La „Passion” des martyrs d'Abitina; remarques sur l'établissement du texte 273-296; A. Harrak - Piecing together the Fragmentary account of the Martyrdom of Cyrus of Harrn 297-328; D.A. Bullough - York, Bede's Calendar and a Pre-Bedan English Martyrology 329-354; B. Joassart - Albert Ehrhard et Hippolyte Delehaye Correspondance 366-400.

11. ANALECTA CRACOVIENSIA 35 (2003):

T. Klibengajtis - Chrystus „wiedzq”, ,gnozq" $i$,pokarmem”. Tytuty logo-chrystologiczne a prawda wedtug Klemensa z Aleksandrii 151-167; G. Czochara Poczq̨ki chrześcijaństwa w Hiszpanii $i$ pisarze hiszpanorzymscy 313-327; K. Kościelniak - Chrześcijańskie piśmiennictwo arabskie przed Mahometem i jego wptyw na islam 329-343.

12. ANNALI DI STORIA DELL'ESEGESI 20 (2003) nr 1:

G. Filoramo - Aspetti dell'identità religiosa 9-23; H. Moxnes - The formation of Christian identity: a Northern perspective 25-38; M. Pesce - Quando nasce il cristianesimo? Aspetti dell'attuale dibattito storiografico e uso delle fonti 39-56; E. Lupieri - La fuga di sabato. Il mondo giudaico di Matteo, seguace di Gesù 57-73; O. Andrei - Aspetti del costruirsi della (e di una) identità cristiana dell'Anticristo di Ippolito 75-110; A. D'Anna - La pseudoepigrafa Corrispondenza tra Paolo e $i$ Corinzi: il suo contesto e la sua funzione nella costruzione di un'identità dottrinale cristiana 111-137; G. Otranto et alii - Il caso di Napoli e della Campania 139-164; A. Saggioro - Rapporti e conflitti tra paganesimo e cristianesimo nel Codice Teodosiano 165-181; C.L. Rosetti - „Se Cristo è in voi". Ricerca storico-esegetica su $R m$ 8, 10, 321-335; G. Aragione - L'episodio di Eracle „al bivio" nella "Seconda Apologia» di Giustino 337-367; F. Vecoli Verso il conflitto tra pagani e cristiani nell'alto Egitto tra $\mathrm{V}$ e V secolo 369-382; F. Fatti - „Eretico, condanna Origene!". Conflitti di potere ad Alessandria nella tarda antichità 383-435; M. del Verme - Aggiornamento bibliografico per lo studio della "Didachè» nel contesto del "Giudaismo cristiano" 455-544.

13. ANUARIO DE HISTORIA DE LA IGLESIA 12 (2003):

G. Fernández - La Acrópolis o Monte Santo de Atenas en la Alta Edad Media 271-276; J.A. Gil-Tamayo - La „Biblia comentada por los Padres de la Iglesia” 281-284; B. Marcotegui Barber - El tratamiento historiográfico de San Hermenegildo 289-302.

14. ANTONIANUM 78 (2003) $\mathrm{nr} 1-4$ :

M. Špelič - Vittorino da Poetovio, profeta diventato esegeta 685-692.

15. APOCRYPHA 14 (2003):

S. Emmel - Preliminary Reedition and Translation of the "Gospel of the Savior»: New Light on the "Strasbourg Coptic Gospel and the Stauros Text from Nubia" 9-53; R. Goulet - Dosithée de Cilicie 55-72; Th.J. Kraus - Die griechische PetrusApokalypse und ihre Relation zu ausgewählten Überlieferungsträgern apokalyptischer Stoffe 73-98; P. Piovanelli - Pre-and Post-canonical Passion Stories. Insights into the Development of Christian Discourse on the Death of Jesus 99128; T. Chartrand-Burke - The Greek Manuscript Tradition of the "Infancy 
Gospel of Thomas»129-151; L. Paulissen - Jésus à l'école. L'enseignement dans l'«Évangile de l'Enfance selon Thomas» 153-175; G. Kreahling Mckay - Christ Polymorphism in Jerusalem. Taphou 14: An Examination of Text and Image 177191; A. Magri - L'esegesi della setta offitica dei Perati. Analisi di Ippolito, «Haer.» V 16, 193-223; F. Jullien - Des „Frères du Seigneur" sur le siège primatial de Perse 225-236; J.P. Pettorelli - Essai sur la structure primitive de la «Vie d'Adam et Eve» 237-256; J. Tromp - The Role of Omissions in the History of the Literary Development of the Greek "Life of Adam and Eve» 257-275; C. Zamagni - Étude critique: Verus Israel. Nuove prospettive sul giudeocristianesimo 277-286.

16. ARCHIV FÜR LITURGIEWISSENSCHAFT 45 (2003) nr 1-2:

Th. O'Loughlin - The Praxis and Explanations of Eucharistic Fraction in the Ninth Century: the Insular Evidence 1-20; C. Leonhard - Die älteste Haggada. Übersetzung der Pesachhaggada nach dem palästinischen Ritus und Vorschläge $z u$ ihrem Ursprung und ihrer Bedeutung für die Geschichte der christlichen Liturgie 201-231; S.K. Langenbahn - „Et Seniores Venerare” (RB 4, 70): Bibliographie Burkhard Neunheuser OSB 1973-2003, 232-319.

17. ARCHIV FÜR RELIGIONSGESCHICHTE 5 (2003):

R.S. Bagnall - N. Gonis - An Early Fragment of the Greek «Apophtegmata Patrum» 261-278.

18. ATENEUM KAPŁAŃSKIE (2003) t. 140 , z. 563-565; t. 141, z. 566-568:

(Z. 564) A.A. Napiórkowski - Czy Kościót rzeczywiście potępit św. Augustyna? Uwagi krytyczne do ksiażki L. Kotakowskiego "Bóg nam nic nie jest dlużny” 289-299; (z. 565) K. Glombik - Ecclesia non sitit sanguinem. Kara śmierci $w$ tradycji Kościoła katolickiego 453-468.

19. ATHENAEUM 91 (2003) nr 1-2:

D. Pérez Sánchez - M. Rodríguez Gervás - Cultura clásica y funcionalidad religiosa en la sociedad gala de la antigiedad tardia 117-144.

20. AUGUSTINIANA 53 (2003) nr 1-4:

B.D. Dutton - Augustine, Academic Scepticism, and Zeno's Definition 7-30; B. Blans - Lyotard and Augustine's «Confessions» 31-51; M. Djuth - Vera Philosophia in Augustine's Thought after 396, 53-68; K.Y. Burchill-Limb - „Philokalia" in Augustine's "De pulchro et apto» 69-75; J. Lössl - Julian of Aeclanum's „Rationalist" Exegesis - Albert Bruckner revisited 77-106; F.B.A. Asiedu - Caritas, Amicitia, and the Ideal Reader: Paulinus of Nola's Reception of Augustine's Early Works 107-138; G. Folliet - Une citation scripturaire ambigu dans les "Confessions" d'Augustin I 5, 6: „non iudicio contendo tecum", allusion à Job 9, 3 à Jérémie 2, 29?, 139-146; P. Parmentier - Pelagius as the bogeyman of Catholics and Protestants in the seventeenth century 147-158; B. Bruns - Die zwei-eine Kirche aus Juden und Heiden 159-264; A. Welkenhuysen - Augustinus in het Nederlands 383-387.

21. AUGUSTINIANUM 43 (2003) nr 1-2:

G.D. Dunn - Clement of Rome and the Question of Roman Primacy in the Early African Tradition 5-24; B. Neil - Rufinus' Translation of the "Epistola Clementis ad Iacobum» 25-39; L. Odrobina - La maxime: „Unus testis nullus testis” ou le 
témoignage de l'évêque au $I V^{e}$ siècle 41-62; C. dell'Osso - Still on the Concept of "enthypostaton" 63-80; R. Villegas Marín - En polémica con Julián de Eclanum. Por una nueva lectura del «Syllabus de gratia» de Próspero de Aquitania 81-124; C. Ricci - La profezia in Gregorio Magno 125-200; M.M. López García - El «De spiritu et litteras en el Concilio de Trento 201-229; M.M. Gorman - The Earliest Latin Commentary on the Gospels 253-312; J.M. Aguinaga - El matririo de conciencia en Origenes y Atanasio según la "Exhortación al Martirio» y la "Vida de Antonio» 313-364; A. Delrio - Il millenarismo di Tertulliano 365-396; S. Borzi - Sull'autenticità del "Contra Hieroclem» di Eusebio di Cesarea 397-416; P. Nehring - Jerome's «Vita Hilarionis». A Rethorical Analysis of its Structure 417-434; M. Marin - Alipio e la topica della conversione ("Conf.»VI 7, 11-12), 435-452; G. Guttilla - La presenza di Vittricio di Rouen nell'opera di Paolino di Nola. Dal «De laude Sanctorum» all'«Epist.» 18 e ai «Carmm.» 17 e 19, 453-471; G. Kalantzis - Theodore of Mopsuestia's "Commentarius in Evangelium Iohannis Apostoli»: Text and Transmission 473-493; S. Voicu - Nestorio e la "Oratio de Epiphania» (CPG 4882) attribuita a Giovanni Crisostomo 495-499.

22. AUGUSTINUS 48 (2003) $\mathrm{nr}$ 188-191:

J.J. Oldfield - Prólogo 5-7; A.I. Bouton-Touboulic - La estética del orden según san Agustín: las imágenes del discurso y del cuadro 9-17; J. Brachtendorf - El declive de la dialéctica en los primeros diálogos de san Agustín 19-25; K.Y. Burchill-Limb - "De pulchro et apto» de san Agustín: obra perdida y nada más? 27-33; C. Burns - Función de los „exempla” de la retórica romana en "La ciudad de Dios» 35-45; K. Coyle - "Contra adversarium legis et prophetarum». De nuevo la pregunta: quién es ese adversario? 47-55; R. Dobbins Silencio y habla en la experiencia de Ostia. El caso de "fons vitae" 57-63; T. Fuhrer - Forma y función de los escritos exegéticos de Agustin 65-82; G. Gillette - Agustín y el significado de las palabras de Perpetua: "Y quedé convertida en varón” 83-93; G. Heidl - „Ordinatissimum Dei munus”. La Trinidad, en “De fide et symbolo» 2, 95-102; D.G. Hunter - Reivindicación de la moralidad bíblica: sexo e historia de la salvación en la reflexión agustiniana sobre los santos hebreos 103-121; T. Kato - „Quid autem amo, cum te amo” «Conf.» 10, 8. Una pregunta agustiniana 123-128; J.P. Kenney - San Agustín y los límites de la contemplación 129-151; C. Kock - Un comentario breve sobre la "Carta" 262 de san Agustín $153-$ 159; J.T. Lienhard - Réplica de Agustín a Maximino: hacia una nueva edición crítica 161-165; S. Mratschek - „Te velimus... consilii participem”. Agustín de Hipona y Olimpio: un ejemplo de cooperación político-religiosa en el siglo $V$, 167-176; H. Müller - Teoría y práctica de la predicación: Agustin, "De doctrina christiana» $y$ «Enarrationes in Psalmos» 177-182; J.M. Norris - El abismo: las tinieblas cósmicas y la depravación espiritual, en las «Confesiones» 183-190; R.K. Raikas - Problemática de la justicia en Agustin 191-213; P. Rigby - Uso agustiniano de universales narrativos en el debate sobre la predestinación 215-228; F.H. Russell - La conversión de Agustín: de la espada a la palabra 229-235; H. Stückelberger - La oración como reflexión sobre sí mismo ante Dios, en la "Carta" 130 de Agustín, escrita a Proba 237-242; J. Torchia - Importancia de la 
„communicatio idiomatum" en la cristologia de san Agustín, con referencia es. pecial a su refutación del uiltimo arrianismo 243-262; F. Van Fleteken - Evolución de la exégesis agustiniana de $R m 7,22-23,263-285$; M.A. Vannier - Aportación del «Sermón» Dolbeau 26, 287-293; H. Van Reisen - Resucitada como verdadera discípula de Señor. Maria Magdalena en la predicación de san Agustín 295-299; D. Weber - La literatura clásica al servicio de la polémica teológica: "Ad Florum», de Juliano de Eclana 301-308; J. Wetzel - La cuestión de la „consuetudo carnalis" en "Conf.» 7, 23, 309-314; D.E. Wright - „Non posse pecare" en esta vida? "De correptione et gratia» 33 de san Agustín 315-321.

23. BIBLIOTHECA SACRA 160 (2003) nr. 637-640:

D.F. Wright - The Making of the Early Christians, cz. 1: The Baptismal Community 3-12; cz. 2: A Race Apart? Jews, Gentiles, Christians 131-141; cz. 3: A Family Faith: Domestic Discipling 259-268; cz. 4: The testimony of Blood: the Charisma of Martyrdom 387-397; J.P. Sweeney - Modern and Ancient Controversies over the Virgin Birth of Jesus 142-158.

24. BIBLISCHE NOTIZEN (2003) nr 116-117:

(Nr 116) H.G. von Mutius - Die judäo-arabische Pentateuchübersetzung von Saadja Gaon zu Genesis 12, 6 im Rahmen der biblischen Textkritik 69-76.

25. BIULETYN ORMIAŃSKIEGO TOWARZYSTWA KULTURALNEGO (2003) $\mathrm{nr}$ 32-34:

(Nr 32/33) A. Pisowicz - Ormianie w Butgarii 39-46.

26. BYZANTINISCHE ZEITSCHRIFT 96 (2003) nr 1-2:

W. Berschin - Graecolatina mediaevalia 5-23; A. Cutler - Imagination and Documentation: Eagle Silks in Byzantium 67-72; M. de Groote - Der byz. Zwölfsilber in Joannes Geometres' Metaphrase der Oden 73-71; J.A. Demetracopoulos - Further evidence on the ancient, patristic, and byzantine sources of Barlaam the Calabrian's "Contra Latinos» 83-122; A. Kambylis - Zu Anna Komnenes Alexias Buch XV 11, 5 (82) - 24 (60), 169-192; T. Papamastorakis Tampering with History: From Michael III to Michael VIII, 193-219; J. Spatharakis - G. Bartholf - An eleventh century illuminated manuscript on Amorgos 217-221; M. Tziatzi-Papagianni - Die Korrespondenz des Theodoros von Kyzikos im Codex Laura W 126: Textkritische Beiträge 223-268; F. Bauer - Statuen hoher Würdenträger im Stadtbild Konstantinopols 433-513; B. Coroke - The Imperial Reigns of Leo II, 559-575; C. Cupane - Wie Volkstïmlich ist die By. zantinische Literatur? 577-599; M. Debié - Du Grec en Syriaque: La transmission du récit de la prise d'Amid (502) dans l'historiographie byzantine 601-622; J. Wintjes - Zur Datierung von Themistius Or. 4, 703-708.

27. BYZANTINOSLAVICA 61 (2003):

W. Mayer - Antioch and the West in Late Antiquity 5-32; H. Gracanin - The Western Roman Embassy to the Court of Attila 53-74; F. Shlosser - The Slavs in Sixth-Century Byzantine Sources 75-82; S. Patri-Les sources des „Lettres syriaques" de la "Vita Constantini» vieux-slave et les figurations littéraires du Logos de la Révelation 83-94; N. Kalogeras - The "Rhetoric of Emulation" in the Work of

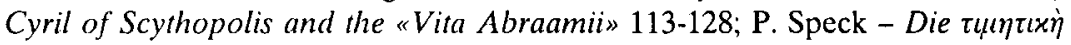




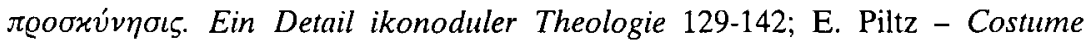
comme communication théologique 169-178; N. Isar - The Dance of Adam. Reconstructing the Byzantine Xo@ós 179-204.

28. CAHIERS DE CIVILISATION MÉDIÉVALE 46 (2003) nr 181-184:

$\mathrm{V}$. Minet-Mahy - Étude des métaphores végétales dans trois commentaires sur le Cantique des cantiques (Origène, Apponius, Bernard de Clairvaux) 159-189.

29. CAHIERS DU CERCLE ERNEST RENAN (2003) nr 221-224:

(Nr 221) R. Levi - Jerôme, portrait d'un faussaire 49-56; (nr 222) J. Deroo - Á propos de la lettre d'Athanase d'Alexandrie 65-79, J. Deroo - Commentaire à propos de la lettre d'Athanase à Épictète, évêque de Corinthe 80-84;

30. CATHOLICA 57 (2003) nr 1-4:

J. Oeldemann - Orthodoxe Theologen im interreligiösen Dialog mit dem Judentum und dem Islam 193-206.

31. CENOBIUM (2003) nr 18:

K. van Oost - Ideat benedyktyński 21-34; P. Rostworowski - Święty Benedykt i jego Reguła 35-59.

32. CERKIEWNY WIESTNIK (2003) nr 1-4:

(Nr 3) J. Charkiewicz - Święte Oblicze 31-37.

33. CHRISTIAN SCHOLAR'S REVIEW 33 (2003) nr 1:

M. Beaty - A.M. Bowery - Cultivating Christian Citizenship: Martha Nussbaum's Socrates, Augustine's "Confessions», and the Modern University 23-54.

34. DER CHRISTLICHE OSTEN 58 (2003) nr 1-6:

A. Audo - Mysterium der Liebe. Ostsyrische Mystiker als Wegweiser in die Spiritualität des christlichen Orients 352-361.

35. CHRISTUS 40 (2003) nr 197-200:

A. Louf - Veilleur, où en est la nuit? 418-426; D. Placide - L'anthropologie chrétienne à la lumière des Pères 37-44.

36. CHURCH HISTORY 72 (2003) nr 1-4:

A. Ferreiro - Simon Magus, Nicolas of Antioch, and Muhammad 53-70.

37. CHURCHMAN 117 (2003) nr 1-4:

R.J.R. Paice - Irenaeus on the Authority of Scripture, the "Rule of Truth" and Episcopacy, (I) 57-70; (II) 133-152; D.W.T. Brattston - Incense in Ante-Nicene Christianity 225-233.

38. CISTERCIAN STUDIES QUARTERLY 38 (2003) nr 1:

K. Russell - John Cassian on Sadness 7-18.

39. CITTEAUX 54 (2003) nr 1-2:

S.R. Cartwright - William of St. Thierry's Use of Patristic Sources in his "Expositions on Romans» 27-54.

40. CLASSICAL PHILOLOGY 98 (2003) $\mathrm{nr}$ 1-2:

F. Dolbeau - A propos d'un „agraphon”: Réflexions sur la transmission de l'homilétique latine antique, avec édition du sermon "Sermo sacerdotis Dei" 160-174; J.A. Francis - Clement of Alexandria on Signet Rings: Reading on Image at the Dawn of Christian Art 179-183. 
41. COLLECTANEA CISTERCIENSIA 65 (2003) nr 1-4:

V. Dupont - Scholastique et Benoût, Macrine et Grégoire 62-67; J.R. Pouchet - La personnalité de S. Basile à travers sa correspondance 147-168; Ch. Roosz - Le Psaume 118 et la «Règle» de saint Benoît 293-309.

42. COLLECTANEA THEOLOGICA 73 (2003) nr 1-4:

(Nr 1) A. Tronina - Judaizm a chrześcijaństwo w I wieku. Koegzystencja czy konfrontacja? 117-138; (nr 2) T. Klibengajtis - Logos wychowawcq Żydów ku prawdzie $w$ koncepcji Klemensa $z$ Aleksandrii. Przyczynek do badań nad filosemityzmem Ojców Kościoła 13-37; (nr 3) T. Klibengajtis - „Nasiona prawdy" pogan. Poezja jako "locus theologicus" wedlug Klemensa $z$ Aleksandrii 61-76.

43. COMMUNIO (PL) 23 (2003) nr 1-6:

(Nr 1) A. Bertolino - Postać Chrystusa we wczesnochrześcijaniskich zabytkach Rzymu, thum. G. Ostrowski 126-153; (nr 2) Y. De Andia - Męczennicy prawdy. Od Ignacego z Antiochii do mnichów z Tibhirine, tlum. M. Żerańska 90-114; (nr 5) L. Pereira Lamelas - „Paresia” męczenników: odwaga $w$ wyznawaniu wiary, tłum. L. Balter 35-50.

44. COMMUNIO (USA) 30 (2003) nr 1-3:

M. Figura - The Eucharist as Sacramental Incarnation 39-56; M. Heinz - Envy and Ingratitude in the "Adversus haereses» of Irenaeus 57-69; R. Brague - Wasted time? 70-78; M. Figura - The Suffering of God in Patristic Theology 366-385; J.P. Batut - Does the Father Suffer? 386-405.

45. CONNAISSANCE DES PÈRES DE L'ÉGLISE (2003) nr 89-92:

(Nr 89: Le culte des reliques) P.I. Fransen - Les reliques: pourquoi les reliques? 2-3; F. Heim - Les honneurs rendus aux martyrs pendant et après les persécutions 4-9; P. Maraval - La découverte de la Croix au IV siècle 10-14; P. Force Vigilance de Calagurris el la critique du culte des reliques. Éléments pour une théologie du culte des reliques 15-26; A. Bonnery - Le développement des villes autour des corps saints durant le Moyen Âge. Exemple de Narbonne 27-34; J.P. Weiss - Le panégyrique de la ville martyriale 35-38; M. Mentré - Reliquaires et reliques - aspects iconographiques 39-41; M.A. Vannier - S. Augustin el le culte des reliques 42-47; J. Siat - Le culte des martyrs d'après les épigrammes de Damase 48-52; P.I. Fransen - Les martyrs Scillitains 53-57; M. Smyth - Les martyrs et la liturgie: l'élaboration du martyrologe latin 58-62; ( $\mathrm{nr}$ 90: La christologie) B. Sesboüé - Les grandes orientations de la christologie patristique 2-14; B. Pottier - La christologie anoméenne d'Eunome de Cyzique, adversaire de Grégoire de Nysse 15-26; M.A. Vannier - Jean Cassien et la christologie à la veille du Concile d'Éphèse 27-38; J. Fantino - L'enseignement christologique du Concile de Chalcédoine 39-44; F. Mali - La christologie de l'Église d'Orient 45-53; G. Kongs - L'identité du Christ 54-59; L. Brottier - In memoriam AnneMarie Malingrey 60-61; (nr 91: L'apport des Pères à la catéchèse d'aujourd'hui actes du colloque des 4 et 5 juillet 2003 à Paris) M. Dubost - Introduction 3-6; A. Dupleix - L'influence des Pères sur l'instrument de travail: „Aller au coeur de la foi" 7-15; M.A. Vannier - Les grandes orientations de la catéchèse des Pères 
16-28; P. Marval - Les catéchèses baptismales (et mystagogiques) de Cyrille de Jérusalem et le témoignage d'Égerie 29-35; Th. Jordan - Catéchèse et liturgie 36-37; Ph. Gueudet - Les retentissements de la catéchèse sur la liturgie 38-42; G. Kongs - Les symboles dans la catéchèse et la mystagogie 43-49; R. Winling - Catéchèse et liturgie chez Grégoire de Nysse 50-58; L. Brottier - Un souci pastoral de Jean Chrysostome: la catéchèse des non-hellénophones 59-67; C. Pasquet - Catéchèse et liturgie dans le monde syriaque 68-77; J. Garcia Les catéchèses eucharistiques de S. Augustin 78-88; C. Dagens - L' initiation à la foi et l'apport des Pères de l'Église 89-97; N.J. Sèd - Transmission de la foi et tradition de l'Église 98-102; R. du Charlat - Art et catéchèse aujourd'hui 103-106; L. Ridez - Catéchèse et iconographie. Un exemple d'iconographie catéchètique inspirée des Pères de l'Église: les enluminures de l'Évangéliaire d'Egbert 108-111; J.C. Reichert - Perspectives actuelles pour la catéchèse 112-116; Ch. van der Plancke - Orientations de la catéchèse Belgique: la catéchèse de la communauté par la communauté 117-122; C. et J. Lagarde - La Bible, parole d'amour 123-125; (nr 92: Saint Maurice) J. Roduit - Présentation générale: la vocation d'une terre 2-3; J.M. Roessli - Le martyre de la Légion Thébaine: culte et diffusion de l'Antiquité tardive au Moyen Âge 4-18; M. Dulaey - Eucher de Lyon: du monachisme à l'épiscopat 19-24; Y.M. Escher - La structure rhétorique de la Passio comme clé d'interprétation 25-35; M.A. Vannier - Le martyre comme „exemplum" pour le moine-évéque Eucher 36-42; E. Chevalley - La Passion anonyme de S. Maurice d'Agaune 43-46; K. Zelzer - L'identification des „Instituta de informatione Acaunensis coenobii": un mystère monastique triangulaire 47-51; P.Y. Fux - Les patries des martyrs: doctrines et métaphores chez quatre poetes de l'Antiquité tardive 52-60.

46. CONTACTS 55 (2003) nr 201-204:

B. Osborne - L'unité de l'Église: une unité trinitaire 8-39; M. Stavrou - L'autorité ecclésiale dans le monde byzantin 148-179; J. van Rossum - L'Eucharistie chez saint Grégoire Palamas; 180-192; V. Lossky - Le problème de la „vision face à face" et la tradition patristique de Byzance 429-455.

47. CREDERE OGGI 23 (2003) nr 133-138:

(Nr 135) P. Sacchi - La storia del Secondo Tempio e le origini cristiane 21-43; (nr 138) R. Grégoire - Cristianesimo e pratiche magiche lungo la storia 87-97.

48. CRISTIANESIMO NELLA STORIA 24 (2003) nr 1-2:

J.A. Jiménez Sánchez - „O amentia monstruosa”. A propósito de la liturgia imperial y del ritual circense durante el siglo V, 23-39; B. Studer - Ein ,anderer Augustinus". Überlegungen zu einem bemerkenswerten Buch 115-133; F. Fatti Tra Costantinopoli e Alessandria: l'edilizia filantropica cristiana al Concilio di

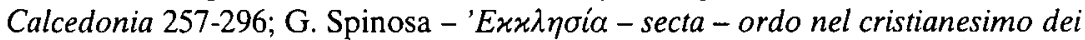
primi secoli: una riflessione sul lessico 453-487; G. Theissen - Urchristentum als Bewegung. Von innerjüdischen Oppositions- und Erneuerungsbewegungen zur Entstehung einer neuen Religion in Römischen Reich 489-515.

49. CZASOPISMO PRAWNO-HISTORYCZNE 55 (2003) nr 1-2: (Nr 1) W. Rozwadowski - Nauczanie prawa w państwie rzymskim 9-28. 
50. DEUTSCHES ARCHIV FÜR ERFORSCHUNG DES MITTELALTERS 59 (2003) nr 1-2:

H. Grahn-Hoek - „Gundulfus subregulus” - eine genealogische Brücke zwischen Merowingern und Karolingern? 1-47; S. Hamann - Zur Chronologie des Staatsreichs Grimoalds 49-96; H. Hoffmann - Der älteste Textzeuge der Chronik des Sulpicius Severus 447-458.

51. DIDASKALIA 33 (2003) nr 1-2:

P. Alves de Sousa - Obras de Santo Agostinho. Ediçōes e traduçōes 227-237; J.M. da Silva Rosa - A tensăo para o fundamento, em Eric Voegelin e Agostinho de Hippona 519-558; C. Nuno Salgado Vaz - Uma agradável surpresa: $O$ «Evangelho segundo Pilatos» 725-743.

52. DISSERTATIONES PAULINORUM 12 (2003):

B. Degórski - Najstarszy monastycyzmu żeński 5-59; Ojcowie Kościola - świadkowie i nauczyciele wiary (rozmowa przeprowadzona przez o. Kazimierza Stefka O.S.P.P.E. z patrologiem o. Bazylim Degórskim O.S.P.P.E.) 84-92.

53. DIVUS THOMAS 106 (2003) nr 34-36:

(Nr 34) C.M. Bondioli - „Gloria Dei vivens homo”. Teologia dello Spirito e antropologia anagogica in Ireneo 241-254.

54. DOCTRINE \& LIFE 53 (2003) nr 1-10:

G. Bonnar - The Incarnation, the Church and the World, according to Augustine 345-357; J. Good - A Theology of the Body: the Legacy of Augustine 358-361.

55. THE DOWNSIDE REVIEW 121 (2003) nr 422-425:

J.R. Fortin - The Reaffirmation of Monastic Hospitality 105-118; J. Moorhead Taking Gregory the Great's «Dialogues» seriously 197-210.

56. EARLY MEDIEVAL EUROPE 11 (2002) nr 1-3:

S. Castellanos - The political nature of taxation in Visigothic Spain 201-228.

57. ECCLESIA ORANS 20 (2003) nr 1-3:

B. Neunheuser - L'epoca della liturgia romana pura pienamente sviluppata $313-$ 320; M.S. Gros - Restes de deux libelli baptismaux romains de la fin du IV siècle 339-355; G. di Napoli - Il sacramentario veronense: i procedimenti nel reperire e trascrivere il materiale e suo impiego 357-396.

58. EDITH STEIN JAHRBUCH 9 (2003):

N. Kuster - Wanderradikale und heimatlose Mönche. Wie eine Lebensform immer wieder sesshaft wird 46-81; M. Lauterborn - Die Benediktinerinnen 8291; J. Schaber - Zwischen Benedikt von Nursia und Ignatius von Loyola. Max Scheler als Interpret des abendländischen Mönchtum 237-254.

59. EFEMERIDES MEXICANA 21 (2003) nr 61-63:

J. Medina Orozco - La "Guerra Justa” desde San Agustín a nuestros dias. Apuntes históricos 223-246.

60. ELPIS 5 (2003) $\mathrm{nr} 7-8$ :

J. Tofiluk - Historia rozwoju i ksztattowania się ptaszczanicy (epitafionu) 11-28; A. Angelopulos - M. Tritos - Instytucja pentarchii w Kościele prawosławnym i jej znaczenie dzisiaj, tłum. J. Pańkowski 87-98.

61. EPHEMERIDES LITURGICAE 117 (2003) nr 1-4: 
B. Neil - The Cult of Pope Clement in Ninth-Century Rome 103-113; M. Barba"Vicarius Petri": la mutevole continuità di un'antica denominazione 385-399; R. Fusco - Dalla liturgia alla storia del dogma: una inedita epitome agiografica (N Auct. BHG 92c) in una raccolta antieresiologica bizantina 405-503.

62. EPHEMERIDES THEOLOGICAE LOVANIENSES 79 (2003) nr 1-4:

J.M. Auwers - Ct 2, 1 au miroir de la chaine de Procope 329-346; D. Ogliari - The Role of Christ and of the Church in the Light of Augustine's Theory of Predistination 347-364; T. Bou Mansour - Une clé pour la distinction des écrits de Isaac d'Antioche 365-402.

63. ERBE UND AUFTRAG 79 (2003) nr 1-6:

A. Böckmann - Zum Prolog der Regel Benedikts: RB Prolog 5-7, s. 5-16; RB Prolog 8-13, s. 124-137; RB Prolog 14-20, s. 224-235; RB Prolog 21-22, s. 308313, RB Prolog 23-35, s. 389-407; RB Prolog 36-39. 40-44 (45-50), s. 487-496; S.Ch. Kessler - Monastische Mystik auf biblischer Grundlage. Theorie und Praxis der Kontemplation bei Gregor dem Großen 17-26; Ch. Reemts - Das christliche Leben als Seefahrt 45-56; E. Barlage - Die Festsetzung von Preisen in der Benediktusregel (RB 57, 7-9) und bei „Weltleuten" unter besonderer Berücksichtigung des Gewinns-Vergleich zweier Ansätze aus volkswirtschaftlicher Sicht 296-307.

64. ESPE (2003) nr 62-65:

(Nr 62) Nie bqqdź surowym sędziq (św. Jan Chryzostom, Hom. do Ew. Mt 23, $1 \mathrm{n}$. I, OZ IIl 212-214), wybral A. Langhammer 69-70; (nr 63) Stowo zamieszkato w ludzkim ciele (św. Atanazy, O Wcieleniu Słowa 8, OŻ I 32-34), wybrał A. Langhammer 70-71; E. Kryściak - Ostra reguła (Pachomiusz) 72; (nr 64) Zbudź się o śpiący (starożytna homilia na Świętą i Wiclką Sobotę, LG II 386388), wybral A. Langhammer 70-71; (nr 65) Nieznajomość Pisma świętego jest nieznajomościq Chrystusa (Hieronim, Komentarz do Ks. Izajasza, Prolog 1. 2, LG IV 1226-1227), wybrał A. Langhammer 75-76; E. Kryściak - $W$ trosce o Źródto Wody Żywej (św. Ireneusz) 76-77.

65. ESTUDIO AGUSTINIANO 38 (2003) nr 1-3:

P. de Luis - Comentario a la Regla de san Agustín. Capítulo cuarto (I) 5-61; (II) 231-290; (III) 517-588.

66. ESTUDIOS FRANCISCANOS 104 (2003) nr 434-435:

I. Jericó Bermejo - Sobre la validez universal del los cánones del sinodo Trullano II. Las opiniones de tres salmantinos del siglo XVI, 93-142.

67. ETUDES THÉOLOGIQUES \& RELIGIEUSES 78 (2003) nr 1-4:

H. Garcia - „Diva Maria”. La promotion divine de Marie dans le christianisme ancien et sa cohérence christologique 225-253.

68. EVANGELISCHE THEOLOGIE 63 (2003) nr 1-6:

W. Huber - Vom Nutzen und Nachteil von Traditionen für das Leben. Die Kirchenväter und die Kirche von morgen 8-24.

69. FAITH AND PHILOSOPHY 20 (2003) nr 1-4:

P.C. Meilaender - The problem of having only one city: an Augustinian response to Rawls 170-188; S. MacDonald - Petit larceny, the beginning of all sin: 
Augustine's theft of the pears 393-414; G.B. Matthews - Augustine on the mind's search for itself 415-429; T.H. Irwin - Augustine's criticisms of the stoic theory of passions 430-447; P. Helm - Augustine's griefs 448-459; L. Rudder Baker - Why Christians should not be libertarians. An Augustinian challenge 460-178; W.E. Mann - To catch a heretic: Augustine on lying 479-495.

70. FAITH \& REASON 28 (2003) nr 1-4:

Ode in Honour of the Holy Immaculate Most Glorious Lady Mother of God and Ever Virgin Mary (written on the occasion of the Deliverance of Constantinople from the Barbarians A.D. 626), transl. with a foreword V. McNabb 89-122; J.A. Varacalli - What Hath Sociology to do with Catholicism? An Orthodox Catholic Response to Tertullian, Comte, and Marx 179-191.

71. FIDES ET HISTORIA 35 (2003) nr 1-2:

(Nr 2) K. Jolly - Historical Empathy, medieval Mentalities, and the Opening of the Evangelical Mind 7-18; Ch.A. Riggs - The History of Concepts. Historical Methodology and the Search for Truth 28-35; D.A. Howard - It Was Called „Palestine": The Land, History, and Palestinian Identity 61-78; J.D. Weaver - Renewing Theology: The Way of John Howard Yoder (Musings from Nicea to September 11), 85-103; W.W. Dickerson III, History as a Teacher of Ethics in the Early Middle Ages 119-130.

72. FORUM TEOLOGICZNE 4 (2003):

M. Wojciechowski - Stoickie definicje cnót wedlug Arejosa Didymosa 177-184.

73. GREEK, ROMAN AND BYZANTINE STUDIES 43 (2002/2003) nr 1-4:

W. Stevenson - Sozomen, Barbarians, and Early Byzantine Historiography 51-75; E.A. Fisher - Planoudes, Holobolos, and the Motivation for Translation 77-104; J. Wortley - Icons and Relics: a Comparison 161-174; M. de Groote - The "Paraphrasis" of Joannes Geometres' "Metaphrasis of the Odes» 267-304; D. Hernández de la Fuente - Nonnus and Theodore Hyrtakenos 397-407.

74. GREGORIANUM 84 (2003) nr 1-4:

A. Miranda - La nozione di "corpo spirituale" in Origene e nella tradizione antiochena 295-314; G.D. Guyon - Sur quelques fondations de la pensée chrétienne des droits de l'homme (I $I^{e r}-1 I I^{e}$ siècles) 828-848.

75. GYMNASIUM 110 (2003) nr 1-6:

K. Döring - Vom Nutzen der heidnischen Literatur für eine christliche Erziehung. Die Schrift "Ad adolescentes de legendis libris gentilium» des Basilius von Caesarea 551-567.

76. HERMENEIA (2002) nr 1-2:

(Nr 1) N. Thon - Die „Drei Hierarchen”. Ihr Leben und ihre Ikonographie 7-26.

77. THE HEYTROP JOURNAL 44 (2003) nr 1-4:

D. King Keenan - The Sacrifice of the Eucharist 182-204.

78. HISTORIA 52 (2003) nr 1-4:

B. Bleckmann - Der Bürgerkrieg zwischen Constantin II. und Constans (340 n. Chr.) 225-250; M. Festy - De l'«Épitome de Caesaribus» à la "Chronique» de Marcellin: l' "Historia Romana» de Symmaque le Jeune 251-255; E. Flaig - Wie Kaiser Nero die Akzeptanz bei der „plebs urbana” verlor. Eine Fallstudie zum 
politischen Gerücht im Prinzipat 351-372; R. MacMullen - Cultural and Political Changes in the $4^{\text {th }}$ and $5^{\text {th }}$ Centuries 465-495.

79. HISTORISCHE ZEITSCHRIFT 276 (2003) nr 1-3:

B. Studt - Helden und Heilige. Männlichkeits Entwürfe im frühen und hohen Mittelalter 1-36; F. Prinz - Die Kirche und die pagane Kulturtradition. Formen der Abwehr, Adaptation und Anverwandlung 281-304.

80. IMPACTS 37 (2003) nr 1-4:

(Nr 2/3) D. Saulnier - Chant grégorien et temporalités 15-25; (nr 4) I.E. Gnarra Sibyls in Anjou 213-238.

81. INTERNATIONAL JOURNAL FOR PHILOSOPHY OF RELIGION 53 (2003) nr 1-3:

(Nr 3) O. Crisp - Augustinian universalism 127-145.

82. IRÉNIKON 76 (2003) nr 1-3:

J. Bandrès - La doctrine christologique de l'Église orthodoxe "Tawahedo" d'Éthiopie. Évolution au cours des siècles 5-46; M. van Parys - L'Église et le Royaume de Dieu. Quelques témoignages des Pères de l'Église 47-63; S.S. Averintsev - Saint Benoît de Nursie et saint Serge de Radonège. Essai de comparaison de deux types spirituals 270-281.

83. IRISH BIBLICAL STUDIES 25 (2003) nr 1-4:

H. Moore - Ph. McCormick - Domitian 74-101; 121-145.

84. IRISH THEOLOGICAL QUARTERLY 68 (2003) nr 1-2:

R.C. Hill - Psalm 41(42): a classic text for Antiochene spirituality 25-33.

85. ISIDORIANUM 12 (2003) $\mathrm{nr}$ 23-24:

C. López Bravo - El legado iusfilosófico de San Isidoro de Sevilla. Ley y derecho en el Libro $V$ de las "Etimologías» 9-30.

86. ISLAM AND CHRISTIAN-MUSLIM RELATIONS 14 (2003) nr 1-4:

J.K.Choksy - Hagiography and Monotheism in History: doctrinal encounters between Zoroastrianism, Judaism and Christianity 407-421.

87. ISTINA 48 (2003) $\mathrm{nr} 1-4$ :

S. Brock - Les origines de quelques termes utilisés dans les épiclèses eucharistiques syriaques 124-135; M. Bawai Soro-Marie dans le dialogue entre catholiques et assyriens dans la perspective assyrienne 136-159; I. Dorfmann-Lazarev - La "Pâque d'Égypte" et la „Pâque de Jérusalem": l'herméneutique de l'Exode dans les traditions chrétienne et rabbinique selon I.Y. Yuval 359-373.

88. JAHRBUCH FÜR LITURGIK UND HYMNOLOGIE 42 (2003):

G. Kurz - Intende qui regis Israel. Der Weihnachtshymnus des Bischofs Ambrosius von Mailand (hy. 5) 105-161.

89. JEWISH STUDIES QUARTERLY 10 (2003) nr 1-4:

M. R. Niehoff - Circumcision as a Marker of Identity: Philo, Origen and the Rabbis on Gen 17, 1-14, 89-123.

90. JOURNAL OF BIBLICAL LITERATURE 122 (2003) nr 1-4:

M.A. Daise - „If anyone thirsts, let that one come to Me and drink": The Literary Texture of John 7, 37b-38a, 687-699.

91. JOURNAL OF EARLY CHRISTIAN STUDIES 11 (2003) nr 1-4: 
G.D. Dunn - Infected Sheep and Diseased Cattle, or the Pure and Holy Flock: Cyprian's Pastoral Care of Virgins 1-20; M.K. Lafferty - Translating Faith from Greek to Latin: "Romanitas" and "Christianitas" in late Fourth-Century Rome and Milan 21-62; D.G. Hunter - Augustine and the Making of Marriage in Roman North Africa 63-86; W. Tabbernee - Portals if the Montanist New Jerusalem: The Discovery of Pepouza and Tymion 87-94; S.R. Harmon - A Note on the Critical Use of "Instrumenta" for the Retrieval of Patristic Biblical Exegesis 95-130; W. Hendrick - The Secret Gospel of Mark: Stalemate in the Academy 133-146; G.G. Stroumsa Comments on Charles Hendrick's Article: A Testimony 147-154; B.D. Ehrman - Response to Charles Hendrick's Stalemate 155-164; F. Bovon - Canonical and Apocryphal Acts of Apostles 165-194; A. Retzleff John Chrysostom's Sex Aquarium: Aquatic Metaphors for Theater in "Homily 7 on Matthew» 195-208; R. Lyman - 2002 NAPS Presidential Address: Hellenism and Heresy 209-222; L. James - Color and Meaning in Byzantium 223-256; A.S. Jacobs - R. Krawiec - Fathers Know best? Christian Families in the Age of Asceticism 257-264; A.S. Jacobs - „Let Him Guard «Pietas»: Early Christian Exegesis and the Ascetic Family 265-282; R. Krawiec - „From the Womb of the Church": Monastic Families 283-308; R.E. Winn - The Church of Virgins and martyrs Ecclesiastical Identity in the Sermons of Eusebius of Emesa 309-338; D. Frankfurter - Syncretism and the Holy Man in Late Antique Egypt 339-386; S. Castellanos - The Significance of Social Unanimity in a Visigothic Hagiography: Keys to an Ideological Screen 387-442; A. Milavec - Synoptic Tradition in the "Didache» Revisited 443-480; Ph.A. Harland - Christ-Bearers and Fellow-Initiates: Local Cultural Life and Christian Identity in Ignatius" "Letters» 481-500;

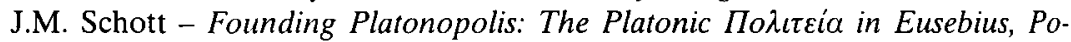
rphyry, and lamblichus 501-532; B.D. Shaw - Judicial Nightmares and Christian Memory 533-563.

92. THE JOURNAL OF ECCLESIASTICAL HISTORY 54 (2003) nr 1-4:

D. Bachrach - Confession in the "Regnum Francorum" (742-900): The Sources Revisited 3-22; S. Tada - The Creation of a Religious Centre: Christianisation in the Diocese of Liège in the Carolingian Period 209-227; D. Bar - The Christianisation of Rural Palestine during Late Antiquity 401-421; M. Penn - Ritual Kissing, Heresy and the Emergence of Early Christian Orthodoxy 625-640.

93. THE JOURNAL OF MEDIEVAL AND EARLY MODERN STUDIES 33 (2003) nr 1-3:

A.S. Jacobs - The remains of the Jew: Imperial Christian Identity in the Late Ancient Holy Land 23-45; D. Brakke - The Lady Appears: Materializations of „Woman" in Early Monastic Literature 387-402; V. Burrus - Macrina's Tattoo 403-417; P. Cox Miller - Is There a Harlot in This Text? Hagiography and the Grotesque 419-435; J.E. Goehring - The Dark Side of Landscape: Ideology and Power in the Christian Myth of the Desert 437-451; D.G. Hunter - Rereading the Jovinianist Controversy: Asceticism and Clerical Authority in the Late Ancient Christianity 453-470; S. Cameron - How to Read Heresiology 471-492; S. Elm Hellenism and Historiography: Gregory of Nazianzus and Julian in Dialogue 
493-515; D.E. Trout - Damasus and the Invention of Early Christian Rome 517536.

94. JOURNAL OF MEDIEVAL HISTORY 29 (2003) nr 1-4:

P. Stephenson - Anna Comnena's "Alexiad" as a source for the Second Crusade? 41-54.

95. THE JOURNAL OF THEOLOGICAL STUDIES 54 (2003) nr 1-2:

P. Spilsbury - Flavius Josephus on the Rise and Fall of the Roman Empire 1-24; P.L. Buck - Justin Martyr's Apologies. Their Number, Destination, and Form 45-59; L. Dossey - The Last Days of Vandal Africa. An Arian Commentary on Job and its Historical Context 60-138; T.C.G. Thornton - High-Priestly Succession in Jewish Apologetics and Episcopal Succession in Hegesippus 160-163; J.R.Harrison - The Fading Crown. Divine Honour and the Early Christians 493-529; D. Woods - Ammianus Marcellinus and Bishop Eusebius of Emesa 585-591.

96. KALISKIE STUDIA TEOLOGICZNE 2 (2003):

R. Pisula - Rozróżnienie obrazu i podobieństwa Bożego w czlowieku u niektórych Ojców Kościoła jako podstawa antropologii teologicznej-przyczynek do tematu 191-198.

97. KERYGMA UND DOGMA 49 (2003) nr 1-4:

B. Oberdorfer-Brauchen wir das Filioque. Aspekte des Filioque-Problems in der heutigen Diskussion 278-292.

98. KIELECKIE STUDIA TEOLOGICZNE 2 (2003):

T. Gacia - Motywy agonistyczne w pismach Cypriana z Kartaginy 201-212;

J. Ihnatowicz - Dlaczego prezbiter nie może udzielać święceń? Biskup i prezbiter w pierwotnym Kościele 213-232.

99. KLIO (2003) nr 3-4:

(Nr 3) J.M. Spychała - Orfeusz i orficy - zarys problematyki 3-24.

100. KWARTALNIK HISTORYCZNY 110 (2003) nr 1-4:

(Nr 1) J. Pysiak - Pogańska przesztość Franków w świetle kilku kronik francuskich z czasów Filipa Augusta i Ludwika Świętego 5-28.

101. LAÓS 10 (2003) nr 1-2œ:

(Nr 2) A. de Maria - Il simbolo e la comunicazione della fede 3-37; G. PutrinoLa dignità sacramentale del matrimonio. Continuità ed attualità della dottrina cattolica 65-83.

102. LAURENTIANUM 44 (2003) nr 1-3:

E. Albrile - L'utero della creazione. Aspetti del sincretismo gnostico 197-216;

$\mathrm{S}$. Vacca - Convivenza tra i popoli e pluralità di religioni in Sicilia durante la prima età normanna 359-389.

103. LAVAL THÉOLOGIQUE ET PHILOSOPHIQUE 59 (2003) nr 1-2:

T. Hegedus - The Magi and the Star in the Gospel of Matthew and Early

Christian Tradition 81-95.

104. LIGNUM VITAE 4 (2003):

J.L. Sima - Święta Góra Atos 479-489.

105. LITERATURE \& THEOLOGY 17 (2003) nr 1-4: 
S.M. Rowley - Reassessing exegetical interpretations of Bede's "Historia ecclesiastica gentis Anglorum» 227-243.

106. LITURGIA SACRA 9 (2003) nr 1-2:

K. Matwiejuk - Koptyjskie dziedzictwo liturgiczne 385-393; A. Turco, Starorzymski spiew liturgiczny ,versus" 411-421.

107. LUMIÈRE \& VIE 52 (2003) nr 257-269:

(Nr 259) B. Meunier - La Providence des premiers chrétiens: de l'évidence à la foi 25-33; (nr 260) J.N. Pèrés - L'identité selon l'Apopogie à Diognète 59-66.

108. LUTHERAN QUARTERLY 17 (2003) nr 1-4:

C. Schneider - Luther's Preface to Bugenhagen's Edition of Athanasius 226-230.

109. ЛУЧА 20 (2003) nr 1:

Б.Б. Брајобић - $O$ демонском и сатанском (огледение у јелинском и хрисићанској философији 17-22; В. Бурђевћ - Апофамичко богословлье Псеудо-Дионисја Ареопагите и логосна структура мишльеньа 23-46.

110. LA MAISON DIEU (2003) nr 233-236:

(Nr 233) M. Smyth - Une avancée oecuménique et liturgique. La note romaine concernant l'anaphore d'Addaï et Mari 137-154; (nr 234) J. Évenou - D'un Martyrologe à l'autre 109-135; ( $\mathrm{nr} 236$ ) J. Guyon - Aux origines du culte des saints (III'-VI siècle): dévotion populaire ou volonté pastorale? Regards sur les Gaules et l'Italie 113-152.

111. MEANDER 58 (2003) nr 1-4:

M. Kozłowska - Wczesne chrześcijaństwo z Brytanii IV-VI wieku na podstawie zabytków archeologicznych $85-97$; M. Starowieyski - Studia z dziedziny historii literatury wczesnochrześcijańskiej i patrologii w Polsce. Próba oceny 163-170; W. Ceran - Omówienie stanu badań bizantynologicznych w Polsce oraz perspektywy rozwoju kadry naukowej (1999-2002), 171-182.

112. MEDIUM AEVUM 72 (2003) nr 1-2:

P. Orton - Stics or stones? The Story of Imma in Cambridge, Corpus Christi College, MS 41 of the Old English Bede, and Old English tn ('twig') 1-12.

113. MÉLANGES DE L'ÉCOLE FRANÇAISE DE ROME 115 (2001) nr 1-2 (Moyen Âge):

J. Dalarun - L. Leonardi - Biblioteca agiografica italiana. Du projet à la publication 7-40; M. Fiano - Il banchetto regio nelle fonti altomedioevali: tra scrittura ed interpretazione 637-682.

114. METHODOS 2 (2003):

H. Paprocki - Diakonisy (historia i wspótczesność) 144-155.

115. MIEJSCA ŚWIĘTE (2003) nr 1-12:

(Nr 1) E. Kozłowski - Kościót cypryjski 13-14; Święty Barnaba (na podstawie: W. Zaleski, Święci na każdy dzień, Warszawa 1989, 313-314), 15-16; E. PukaczProdromou - Krzyz nad Lewantem 21-23; (nr 3) J. Naumowicz - Ojcowie pustyni. Miejsce próby 5-6; J. Strzelczyk - Rzymska Afryka chrześcijaniska 7-9; (nr 4) J. Strzelczyk - Męczeństwo Perpetui, Felicyty i towarzyszy 6-10; J.S. Partyka - Święty Cyprian - biskup Kościota afrykańskiego 11-15; J.S. Partyka - Fulgencjusz z Ruspe 16-17; (nr 7) A. Kuśmirek - Jakub Starszy Apostol 
6-7; T. Sobolska - Dzieje Księgi Apostoła Jakuba 10-12; J. Strzelczyk - Wizygoci w Hiszpanii - od arianizmu do katolicyzmu 26-28; J. Kotański - Rekonkwista 29-30;

116. MIESIĘCZNIK PASTERSKI PŁOCKI 88 (2003) nr 1-12:

A. Majchrzak - Symbol w kulturze chrześcijańskiej 286-297.

117. MITTELLATEINISCHES JAHRBUCH 38 (2003) nr 1-2:

A. Dihle - Prudentius, "Psychomachia" 454ff., 17-18; J. Szvérffy - Beiträge zur Typengeschichte der lateinischen Hymnen. Grundlage einer umfassenden Hymnengeschichte? 39-49.

118. MNEMOSYNE 56 (2003) nr 1-6:

T.J. Leary - Ausonius «Epigram» 77: The Doctor, the Diviner and the Dying Man 358-360; D. Holwerda - Textkritisches zum Basilides-Referat des Hippolytos 597-606.

119. MODERN THEOLOGY 19 (2003) nr 1-4:

H. Boersma - Irenaeus, Derrida and Hospitality: On the Eschatological Overcoming of Violence 163-189; M.R. Barnes - The Visible Christ and the Invisible Trinity: Mt 5, 8 in Augustine's Trinitarian Theology of 400, 329-355; M. Hanby Augustine and Descartes: An Overlooked Chapter in the Story of Modern Origins 455-482.

120. MORALIA 26 (2003) $\mathrm{nr}$ 1-4:

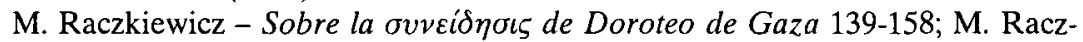
kiewicz - La paz, una prioridad para los Padres de la Iglesia 397-416.

121. MÓWIĄ WIEKI (2003) nr 1-12:

(Nr 5) Od wspólnoty zakonnej do spoteczeństwa. Rozmowa z prof. Jerzym Kloczowskim 11-16; (nr 6) E. Wipszycka-Bravo - Rzym - państwo naszych marzeń 8-12; M. Wojtkowska - Po drugiej stronie Tybru 20-25; M.J. Leszka Chan Krum - nowy Sennacherim 38-42; (nr 10) R. Suski - Wikingowie starozytności 8-12

122. MÜNCHENER THEOLOGISCHE ZEITSCHRIFT 54 (2003) nr 1-4:

Ch.G. Müller - Priska und Aquila. Der Weg eines Ehepaares und die paulinische Mission 195-210.

123. NEDERLANDS THEOLOGISCH TIJDSCHRIFT 57 (2003) nr 1-4:

$\mathrm{K}$. Vriezen - „De leeuw zal stro eten als het rund. De wolf en het lam zullen tezamen weiden". Een Oudoosters paradijsthema in mozaeken in Byzantijns Palestina/Arabia 126-134.

124. NEUE ZEITSCHRIFT FÜR SYSTEMATISCHE THEOLOGIE UND RELIGIONSPHILOSOPHIE 45 (2003) nr 1-3:

J. Wirsching - Augustinus der lateinische Grieche 1-19.

125. NEW BLACKFRIARS 84 (2003) nr 1-12:

S.D. Moringiello - Kataphasis, Apophasis and Mysticism in Pseudo-Denys and Wittgenstein 220-229.

126. NEW TESTAMENT STUDIES 49 (2003) nr 1-4:

M. Goulder - Hebrews and Ebionites 393-406.

127. NICOLAUS 30 (2003) nr 1-2: 
T.M. Violante - Fu vero scisma? I rapporti Roma - Costantinopoli nel secolo undecimo 27-83; P. Corsi - Cultura bizantina nel Mezzogiorno normanno-svevo 85-104; D. Mongillo - L'ammirazione per Dio, fine ultimo: ispirazione e coronamento della bontà del volere e dell'operare amico. L'eredità dei Padri latini e greci 167-184; A. Moda - Simeone il Nuovo Teologo. „Il Rinnovatore della vita mistica" 219-271; G. Donato - La "Vita Antonii» di Atanasio: Ascesi e lavoro 273-284; R. Simini - La donna nella tradizione ebraica e cristiana 347-365; N. Bux - Appunti per una mistagogia antica e nuova 367-373.

128. NOVUM TESTAMENTUM 45 (2003) nr 1-4:

D.M. Scholer - Bibliographia Gnostica: Suplementum II/6, 71-104

129. IL NUOVO AREOPAGO 22 (2003) nr 1-4:

(Nr 1) F. Ventorino - Chiesa e struttura politica nel cristianesimo primitivo. A proposito del libro di Hugo Rahner 58-71.

130. NURT 37 (2003) t. 101-104:

(T. 102): A. Miotk - Misje czasów apostolskich i zasięg chrześcijaństwa do IV wieku 43-74.

131. O ODIGOS 22 (2003) nr 1-4:

(Nr 1-2) E. Sironi - La radice di uno stile di relazione comune all'Oriente e all'Occidente 5-7; L. Lorusso - La Chiesa Cattolica Caldea 19-22; (nr 3) G. Cioffari - L'iconografia di San Nicola nel retaggio bizantino della Puglia fra $X I$ e $X V$ secolo 5-23;

132. OBNOVLJENI ŽIVOT 57 (2002) nr 1-4:

S. Kos - Ženidba kao put spasenja u spisima svetog Ivana Zlatoustoga 43-72.

133. ONE IN CHRIST 38 (2003) $\mathrm{nr}$ 1-3:

P. Reardon - The "Aeneid» and the Acts of the Apostles 45-55.

134. ORDENS NACHRICHTEN 42 (2003) nr 1-5:

(Nr 2) M. Puzicha - Die Benediktusregel. Ein Zeugnis für Menschen von heute 34-40.

135. ORIENS CHRISTIANUS 87 (2003):

A. Palmer - Paradise restored 1-46; P. Bruns - Von Adam und Eva bis Mohammed. Beobachtungen zur syrischen Chronik des Johannes bar Penkaye 47-64; H. Kaufhold - Anmerkungen zur Textïberlieferung der Chronik des Johannes bar Penky 65-79; S. Talay - Neue syrische Grabinschriften aus Qasrk (Nordostsyrien) aus dem Jahre 327-330 H., 80-99; J.R. Zaborowski - Egyptian Christians Implicating Chalcedonians in the Arab Takeover of Egypt: The Arabic Apocalypse of Samuel of Qalamün 100-115; Y. Nessim Youssef - Coptic fragment of a letter of Severus of Antioch 116-123; A. Sima - „Konä yaqütbl" in einer Wiener Handschrift des äthiopischen Danielbuches. Ein Beitrag zur Textgeschichte des altäthiopischen Daniel und zur Sprachgeschichte des Ge'ez 123-129; S.B. Chernetsov - A short story of St. Täklä Haymanot's ancestors and his «heritage» (rist) in the Däbra-Libanos version of his Vita 130-139; M. Kropp - Viele fremde Tische, und noch einer im Koran: Zur Etymologie von äthiopisch „ma' $2 d(d \mathfrak{d})$ ” und arabisch "mä'ida/mayda 140-143; M. van Esbroeck - Der armenische Ikonoklasmus 144-153; N. Doborjginidze - Einige Fragestellungen der Volksspra- 
chenemanzipation im östlichen Christentum des Mittelalters 154-174; D. PiguetPanayotowa - The Church of Oschki. Architecture und Ornaments (part 2) 175219; G. Rabo - Die Publikationen von Professor Dr. Werner Strothmann (19071996), 220-223.

136. ORIENTALIA CHRISTIANA PERIODICA 69 (2003) nr 1-2:

A. Ammassari - La struttura carismatica della Comunità Siro-Cinese a Xian-fu (635-845) e il suo Tempio di Daqin. Tradizioni proto-evangeliche del "Sutra di Gesù Messia" 29-71; G. Winkler - A Remarkable New Publication by R.W. Thomson about the Teaching of Saint Gregory the Illuminator 153-162; R.E. Carter - The Image of God in Man and Woman according to Severian of Gabala and the Antiochene Tradition 163-178; E.Ch. Suttner - Wandel im Verständnis von Schisma und Union. Von Bischof Cyprian von Karthago bis ins 20. Jh. 267-285; M. Dubuisson - C. Macé - L'apport des traductions anciennes à l'histoire du texte de Grégoire de Nazianze. Application au Discours 2, 287340; D.M. Searby - A Paraphrase of Gregory of Nazianz "Carmen de virtute» 2, 9, in an Uppsala Ms. 341-353; Z. Pogossian - Women at the beginning of Christianity in Armenia 355-380; A. Ammassari - La soteriologia della stele di XianFu e il sutra pneumatologico „Riposo e gioia” 381-428.

137. ORTHODOXES FORUM 17 (2003) nr 1-2:

F. Gahbauer - Der „Leuchter” als Symbol fïr theologische und geistliche Aussagen der Kirchenväter 7-28; Ch. Baloglou - Theodoret of Cyrrhus' Economic Thought 77-80.

138. OSTKIRCHLICHE STUDIEN 52 (2003) nr 1-4:

P. Plank - Der hymnographische Beitrag des Theophanes Graptos zur Geschichte seiner eigenen Familie 316-330.

139. PASTORES (2003) nr 18-21:

(Nr 18) Ikona Bożego Narodzenia 116-123; (nr 19) J. Woliński - Zmartwychwstanie, Ojcowie Kościoła i my 100-108; (nr 20) J. Naumowicz - Kwiaty na pustyni 119-124; (nr 21) J. Naumowicz - Św. Augustyna droga do celibatu 109-115.

140. PATH 2 (2003) nr 1:

(Nr 1) N. Cipriani - Il mistero trinitario nei Padri 47-70; Y. Spiteris - Teologia trinitaria nell'Oriente cristiano: implicazioni soteriologische e antropologiche 71-93.

141. PHILOLOGUS 147 (2003) nr 1-2:

P. van Nuffelen - Dürre Wahrheiten. Zwei Quellen des Berichts von Socrates Scholasticus über die Versorgungskrise in Antiochien 362/363, 352-356; M. Hoffmann - Lazarus als wiederstandener Phönix: Sedulius, "Carmen Paschale» 4, 290, 364-366.

142. PHILOSOPHISCHES JAHRBUCH 110 (2003) nr 1-2:

Ch. Kann - Grenzen des Zweifels. Skeptizismuskritik bei Augustinus, Heinrich von Gent und Descartes 226-240.

143. PHOENIX 57 (2003) nr 1-2:

M. Carter - Gladiatorial ranking and the «SC de pretiis gladiatorum minuendis» (CIL II 6278 = ILS 5163), 83-114; A. Retzleff - Near Eastern Theatres in Late Antiquity 115-138. 
144. PIELGRZYM 14 (2003) nr 1-26:

(Nr 3) M. Starowieyski - Kościoły przedchalcedońskie (1), 24; (nr 4) Sobory Efeski i Chalcedonski (2), 24; (nr 5) Zawsze wierni-maronici (3), 24; (nr 6) Dziedzictwo Soboru Efeskiego (1) - Kościót Chaldejski 23-24; (nr 7) Dziedzictwo Soboru Efeskiego (2) - Kościoty w Indiach 24; (nr 8) Dziedzictwo Soboru Chalcedoniskiego (1) - Koptowie 23-24; (nr 9) Dziedzictwo Soboru Chalcedońskiego (2) - Melkici 24; (nr 10) Dziedzictwo Soboru Chalcedońskiego (3) Kościoly syryjskie 22-23; (nr 11) Dziedzictwo Soboru Chalcedońskiego (4) Ormianie 23-24; (nr 12) Dziedzictwo Soboru Chalcedońskiego (5) - Etiopczycy 24; (nr 13) Mozaika Kościołów Wschodu 24; (nr 14) Sobór Watykański II 24; (nr 15) Dlaczego Kościoły Wschodnie? 24; (nr 26) Moja Italia (1). Campo Verano 22-23.

145. POLONIA SACRA 7 (2003) nr 12-13:

(Nr 12) P. Sikora - Przebóstwienie czlowieka. Chalcedon i chrystologia dwustopniowa 327-339.

146. POZNAŃSKIE STUDIA TEOLOGICZNE (2003) nr 14-15:

(Nr 14) A. Weiss - Vom Heiligen Stuhl unmittelbar abhängige Bistümer in mittelalterlichen Europa 147-159; (nr 15) A. Swoboda - Obraz zony w pismach Seneki i w "Objaśnieniach Psalmów» (Enarrationes in Psalmos) św. Augustyna 91-109.

147. PRO DIALOGO (2003) nr 112-114:

N. Sheth - Apostles, Martyrs, Saints and Doctors of the Church in Christianity $185-212$.

148. PRO ECCLESIA 12 (2003) nr 1-4:

F. Guyette - John Cassian on Faith and Action. Implications for ProtestantCatholic Dialogue 89-98; A. Golitzin - Dionysius Aeropagita? A Christian Mystycism? 161-212; J. Driscoll - Uncovering the Dynamic "lex orandi - lex credendi" in the Baptisaml Theology of Irenaeus 213-225.

149. PROCHE ORIENT CHRÉTIEN 53 (2003) nr 1-4:

Pierre Chrysologue - Il mange avec les publicains et les pécheurs (Sermo 30, PL 52, 285-286), trad. des moines bénédictins d'En Calcat, Tarn, France 3-4; S. Khalil Samir - L'Esprit Saint dans la liturgie copte 5-33; S. Le Mong - Le "démon de midi", des déserts d'Égypte à aujourd'hui 34-50; J. Chrysostome Tendre les voiles au souffle de l'Esprit 227-228; F. Leduc-Modération, douceur et mansuétude dans l'oeuvre de Jean Chrysostome 229-259; L. Perrone - Prayer and the Construction of Religious Identity in Early Christianity 260-288.

150. PRUDENTIA 35 (2003) nr 2:

D.M. Gwynn - The Construction of a , heretical party" in the "Apologia contra Arianos" of Athanasius of Alexandria 161-187.

151. PRZEGLĄD HISTORYCZNY 94 (2003) nr 1-4:

E. Jastrzębowska - Księdza Bohusza poglądy na rzymskie katakumby z 1791 roku 137-148; P. Janiszewski - Neoplatonik historykiem. Magiczne posagi, theur-

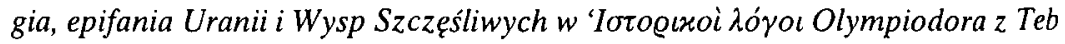
377-395. 
152. PRZEGLĄD NAUK HUMANISTYCZNYCH 2 (2003) nr 1-2:

(Nr 2) M.B. Leszka - Między zwolennikami anomeizmu a homejczykami biskupie peregrynacje Eudoksjusza z Germanikei 5-28.

153. PRZEGLAZD POWSZECHNY (2003) nr 1-12:

(Nr 1) I Oda Salomona, tłum. i oprac. R. Zarzeczny 9; (nr 2) Przystowie etiopskie, tłum. i oprac. R. Zarzeczny 153; (nr 3) Wychwalać będziemy Zwycięzcę mocnego... (fragm. bizantyjskich hymnów paschalnych z IX wieku), tłum. i oprac. R. Zarzeczny 281-282; (nr 4) Z Homilii paschalnej Pseudo-Atanazego, thum. i oprac. R. Zarzeczny 9-10; (nr 5) Modlitwa Maryi za Kościót, tłum. i oprac. R. Zarzeczny 181-182; (nr 6) T.P. Terlikowski - Jedyni prawdziwie prawoslawni 404-414; Modlitwy ludu Etiopii, thum. i oprac. R. Zarzeczny 415-416; (nr 7-8) Litania o świętym Krzyżu, tłum. i oprac. R. Zarzeczny 122-123; (nr 9) Maryjo, Tyś Bramq Ś wiatłości, tłum. i oprac. R. Zarzeczny 314-315; (nr 10) M. Medvid Prawostawne Kościoty autokefaliczne 50-65; Przystowie etiopskie II, tłum. i oprac. R. Zarzeczny 91; (nr 11) T.P. Terlikowski - Chrześcijanie przedefescy, czyli o nestorianizmie jako pewnym nieporozumieniu chrystologicznym 240250; Etiopska modlitwa Mojzesza, thum. i oprac. R. Zarzeczny 251-254; (nr 12) Przedziwny cud na niebiosach. Z homilii Pseudo-Epifaniusza ku czci Najświętszej Maryi Panny 452-453.

154. PRZEGLĄD PRAWOSEAWNY (2003) nr 1-12:

(Nr 11) D. Wysocka - Pentarchia dawniej i dziś 22-23.

155. PRZEGLĄD RELIGIOZNAWCZY (2003) nr 207-210:

(Nr 208) Z.I. Brzostowski - Józef Flawiusz w obliczu próby wierności 31-40; W. Gajewski - Judeochrześcijańska struktura gminy jerozolimskiej od dodeka do episkopatu 41-63; J. Iluk - Augustyna, biskupa Hippony, rozprawa o Żydach i judaizmie 65-83; J. Iluk - Bibliografia dziejów judaizmu i chrześcijaństwa w spoteczeństwach hellenistyczno-rzymskich 117-168.

156. PRZEGLĄD TOMISTYCZNY 9 (2003):

M. Niewiadomska - Wiersze o Krzyżu Wenancjusza Fortunata. Próba interpretacji 281-311.

157. QUADERNI DI STORIA 29 (2003) nr 57-58:

(Nr 57) E. Merendino - Johannes Irmscher, classicista europeo (1920-2000). Bibliografia di Johannes Irmscher (1948-2001) 223-280; (nr 58) V. Cuomo Fozio e Giovanni Crisostomo in un anonimo viennese 125-139.

158. QUADERNI MEDIEVALI (2003) nr nr 55-56:

(Nr 56) P. Marone - Le opere di Gregorio Magno 140-145.

159. QUESTIONS LITURGIQUES 84 (2003) nr 1-4:

M. Kadavil - World as Sacrament: Ethical and Lifurgical Response to Creation in Saint Ephrem 5-22; S. Verhelst - Histoire ancienne de la durée du carême à Jérusalem 23-50; J. Lamberts - The Origin of Confirmation revisited 98-127.

160. RASSEGNA DI TEOLOGIA 44 (2003) nr 1-6:

Z. Pogossian - Il ruolo delle donne nella conversione dell'Armenia 77-88;

P. Sguazzardo - La recensione di Agostino nel pensiero di Karl Rahner 221246. 


\section{RECHERCHES AUGUSTINIENNES 33 (2003):}

J.P. Bouhot - La tradition catéchétique et exégétique du "Pater noster" 3-18; $\mathrm{R}$. Gounelle - A propos des volailles cuites qui ont chanté lors de la passion du Christ 19-61; J. Fontaine - Isidore de Séville et la Bible 65-69; M. Dulacy Isidore de Séville témoin du "Commentaire sur la Genese» de Victorin de Poetovio 71-94; D. Potrel - Un manuel d'exégèse spirituelle al service des prédicateurs: les "Allegoriae" d'Isidore de Séville 95-107; O. Szerwiniack - Bede et les interprétations des soms hébreux 109-154; J.M. Picard - L'exégèse irlandaise des Épitres se saint Paul: Les gloses latines et gaéliques de Würzburg 155-167.

162. RELIGIÓN Y CULTURA 49 (2003) nr 224-227:

J. Tejedor Andrés - San Agustín y la audencia episcopalis 129-142.

163. RESURRECTION (2002) nr 98:

A. Grau - Le concile de Chalcédoine et l'embryon 37-53.

164. REVISTA AGUSTINIANA 44 (2003) nr 133-135:

J.V. Ganzarolli de Oliveira - Estética de San Agustín: problemas de ayer, problemas de hoy 361-375; G. Folliet - L'explication par Augustin dans ses "Confessions" X 1, 1 du mot "confessio": , qui facit veritatem venit ad lucem" (Jean 3, 21), 543-549; J.M. Zamora Calvo - La Prudencia en el Tratado "Sobre José» de Filón de Alejandría 623-642; J.R. Flecha Andrés - Moral del seguimiento de Cristo en los Padres de la Iglesia 643-674.

165. REVISTA DE ESPIRITUALIDAD 62 (2003) nr 246-249:

D. de Pablo Maroto - Espiritualidad de los Padres del Yermo. Pasado y vigencia en nuestro tiempo 41-78.

166. REVISTA ESPAÑOLA DE TEOLOGÍA 63 (2003) nr 1-4:

C. Álvarez Alonso, Notas trinitarias para una pneumatologia de la virginidad según san Ambrosio 471-497.

167. REVISTA TEOLOGÍA 40 (2003) nr 1-2:

(Nr 1) M. Pollitzer - Diocleciano y la teología tetrárquica 157-166.

168. REVISTA TEOLOGICĂ 13 (2003) nr 1-4:

(Nr 1) C. Oancea - Profetul Ilie in exegeza patristică 47-72; L. Grozea - Cazul Bardesane. O dilemă patristică sau filozofic ă? 73-82; (nr 4) N. Chifăr - Unitate in diversitate. Evolutia istorică a Bisericilor in primul mileniu creştin 34-44.

169. REVUE BÉNÉDICTINE 113 (2002) nr 1-2:

A. de Vogüé - L'influence de saint Basile sur le monachisme d'Occident 5-17; G. Partoens - Le sermon 151 de saint Augustin. Introduction et édition 18-70; P. Meyvaert - A. Davril - Théodulfe et Bède au sujet des blessures du Christ 71-79; P.I. Fransen - Extraits non encore repérés dans la compilation augustinienne de Florus sur l'Apôtre 80-89; F. Dolbeau - J. Lemarié - Une traduction latine inconnue d'un sermon pseudo-chrysostomien sur le baptème du Christ (CPG 4522), 217-234.

170. REVUE BIBLIQUE 110 (2003) nr 1-4:

N.H. Taylor - Stephen, the Temple, and Early Christian Eschatology 62-85; W.J. Fulco - An Early Christian Lamp from Aswan inscribed NEOMICT (Planche I), 86-88, A. Falcetta - The Logion of Matthew 11, 5-6 par. from 
Qumran to Abgar 222-248; M.É. Boismard - Étude sur le papyrus copte de l'évangile de Matthieu provenant de la collection Schфyen 387-398.

171. REVUE DE L'HISTOIRE DES RELIGIONS 220 (2003) nr 1-4:

N. Ibrahim Fredrikson - La perle, entre l'océan et le ciel. Origines et évolution d'un symbole chrétien 283-317.

172. REVUE DES ÉTUDES AUGUSTINIENNES 49 (2003) nr 1-2:

G. Madec, In memoriam Albert de Veer 3-4; J. Alexandre, L'étonnement chez Tertullien 5-23; G. Guttilla, Alcune note critiche sui «Carmina» di Paolino di Nola 25-41; M. Dulaey, L'apprentissage de l'exégèse biblique par Augustin. (2) Années 390-392, 43-84; G. Partoens, Le "Sermon» 176 de saint Augustin sur 1 Tim. 1, 15-16, Ps. 94, 2/6 et Lc. 17, 11-19, 85-122; Y.M. Duval, Note sur la lettre d'Evodius à l'abbé Valentin d'Hadrumète, 123-130; E. Decrept, L'arrière-plan liturgique et ecclésial des Actes d'Ignace, 131-166; Y. Hen, A Merovingian Commentary on the Four Gospels, 167-187; Y. Duval, Sur les conciles africains antérieurs à Cyprien 239-251; X. Dupuis, Hagiographie antique et histoire: l'exemple de la "Passion de Lucius et de Montanus», 253-265; B. Pouderon, $M v \theta \omega \delta \bar{\omega} \zeta, \mu v \sigma \tau \iota x \tilde{\omega} \zeta$. L'herméneutique de la "Cohortatio ad Graecos» restituée à Marcel d'Ancyre 267-283; F. Dolbeau, Un nouveau témoin du «Sermon» $20 B$ d'Augustin sur la santé corporelle 285-296; G. Raspanti. San Girolamo e l'interpretazione occidentale di Gal 2,11-14, 297-321; Ch. Veyard-Cosme, Saint Jérôme dans les lettres d'Alcuin: de la source matérielle au modèle spirituel 323351; Chronica Tertullianea et Cyprianea 2002,353-390.

173. REVUE DES SCIENCES HUMAINES (2003) nr 269-272:

(Nr 269) J.Ph. Pierron - La dimension figurative du témoignage. L'exemple des premiers martyrs chrétiens $15-32$.

174. REVUE DES SCIENCES PHILOSOPHIQUES ET THÉOLOGIQUES 87 (2003) $\mathrm{nr} 1-4$ :

M. Morard - Une lettre du Père de Lubac à Jean Châtillon et un épisode récent de la théologie du ministère sacerdotal 293-302; M. Canévet - Les «Confessions» de Saint Augustin. Un voyage spirituel 549-556.

175. REVUE DES SCIENCES RELIGIEUSES 77 (2003) nr 1-4:

V. Saxer - L'Église et l'empire chrétien au IV siècle. La difficile séparation des compétences devant les problèmes doctrinaux et ecclésiologiques 11-30; F. Heim - Le Dieu et sa statue. Des traces d'hermétisme chez les apologistes latins 31-42; M. Fédou - Henri de Lubac, lecteur d'Origène 133-146; E. Decrept - Trois représentations de l'Incarnation et leur arrière-plan d'après les «Lettres» d'Ignace d'Antioche 275-286; B. Munier - L'Apologie de Justin: notes de lecture 287-300; A. Faivre - Après Jésus, quel serviteur? 301-322; M. Bratu - Quelques aspects de la théorie de l'icône de S. Théodore Studite 323-349.

176. REVUE D'HISTOIRE DE L'ÉGLISE DE FRANCE 89 (2003) nr 222-223:

$\mathrm{Ph}$. Bernard - Les diptyques du monastère des saints-Apôtres d'Arles au VII siècle. Édition critique et commentaire 5-21.

177. REVUE D'HISTOIRE ECCLÉSIASTIQUE 98 (2003) t. 1-4:

J.M. Auwers - Les Pères, lecteurs de l'Écriture. Chronique d'exégèse patristique 
106-127; J.M. Auwers - J.B. Demoulin - „Metator”: un cas d'appropriation chrétienne de terme institutionnel romain 389-417; V. Sommers - Chronique nazianzène 516-524.

178. REVUE D'HISTOIRE ET DE PHILOSOPHIE RELIGIEUSES 83 (2003) nr 1-4:

M. Philonenko - Le Vivificateur. Étude d'eschatlogie comparée (de 4Q521) aux «Actes de Thomas» 61-69; R. Roukema - L'origine du mal selon Origène et dans ses sources 405-420.

179. REVUE MABILLON 14 (2003) t. 75 :

A. de Vogüé - La législation de Justinien au sujet des moines 139-151.

180. REVUE THÉOLOGIQUE DE LOUVAIN 34 (2003) nr 1-4:

J.M. Auwers - La Bible et les Pères. Chronique d'exégèse patristique 187-211.

181. REVUE THOMISTE 103 (2003) nr 1-4:

E. Perrier - L'enjeu christologique de la satisfaction (I) 105-136; (II) 203-247; Augustin - „Sur les idées (Quaestio de ideis)", traduction et notes de lecture par G. Madec 358-362; D. Doucet - „De ideis": Éclipse ou dissemination? Les lections in Boethium "De Trinitate» attribuées à Thierry de Chartres (II 35-67), 363-384; A. Robert - Idées humaines, idées divines: Ockham lecteur d'Augustin 479-493.

182. RICERCHE DI STORIA SOCIALE E RELIGIOSA 30 (2002) nr 61-62:

(Nr 62) C. Alzati - Chiesa romana e Oriente cristiano tra storia ed ecclesiologia 7-35; E. Massa - Gregorio Magno e l'arte del linguaggio. Ovvero scrittura e spiritualità 53-101.

183. RICERCHE STORICO BIBLICHE 15 (2003) nr 1-2:

(Nr 2) P. Grech - Il giudeo-cristianesimo. Lo stato della questione 7-20; M. Pesce - Sul concetto di giudeo-cristianesimo 21-44; G. Marconi-Giacomo e il giudeo. cristianesimo nel I secolo 45-74; E. Manicardi - La missione per $i$ giudei e il carattere giudeo-cristiano del Vangelo secondo Matteo 75-102; A. Pitta - Gli avversari giudeo-cristiani di Paolo 103-120; F. Manns - Une source rabbinique sur le judéo-christianisme 121-168; L. Cirillo - Giacomo e Pietro nelle "PseudoClementine»169-186; C. Gianotto - Gli sviluppi del giudeo-cristianesimo 187200; R. Penna - Inizi e primi percorsi della cristologia giudeo-cristiana 201-232.

184. RIVISTA BIBLICA 51 (2003) nr 1-4:

A. Manzi - La figura di Mosè nell'Epistola agli Ebrei e nel "Dialogo con Trifone» 3-55.

185. RIVISTA DI ARCHEOLOGIA CRISTIANA 79 (2003) nr 1-2:

D. Mazzoleni - Padre Antonio Ferrua S.I. (1901-2003), 3-8; D. Mazzoleni Mario Mirabella Roberti (1909-2002), 9-11; F. Bisconti - Scena di commercio del vino in un rilievo inedito della regione dell'ex vigna Chiaraviglio in S. Sebastiano 15-44; C. Carletti - Nuove iscrizioni dalla regione di $S$. Eunchio nel cimitero di S. Sebastiano 45-89; R. Giuliani - C. Noviello - F. Tommasi - Ancora sulla regione $G$ della catacomba dell'ex vigna Chiaraviglio (via Appia): conferme e nuove acquisizioni dallo studio dei materiali 91-146; C. Angelelli - Nuovi frammenti di scultura altomedievale dal territorio ternano 149-171; M. Bianchini 
- M. Vitti - La basilica di San Michele Arcangelo al VII miglio della via Salaria alla luce delle scoperte archeologiche 173-242; G. Cipriano - Il mausoleo dell'Esodo di el-Bagawat. La lettura iconografica del programma decorativo della cupola 243-288; M. Ghilardi - Le pitture della villa di Lullingstone quaranta anni dopo lo scavo: note per una rilettura 289-312; S. Heid - Der SinaiBerg der Gottesschau in frühkirchlicher Tradition 313-358; B. Joassart - Giovanni Battista de Rossi et Louis Dr:chesne. Lettres inédites 359-363; R. Martorelli - D. Mureddu - F. Pinna - A.L. Sanna - Nuovi dati sulla topografia di Cagliari in epoca tardoantica ed altomedievale dagli scavi nelle chiese di $S$. Eulalia e del S. Sepolcro 365-408; C. Noviello - Su alcuni disegni di interesse concordiese del Cod. Vat. Lat. 10524 (con osservazioni sui sarcofagi di Concordia) 409-467; R. Wisskirchen - Der Fassadenschmuck von Alt-St.Peter in Rom und anderen Basiliken 469-494.

186. RIVISTA DI TEOLOGIA. ASPRENAS 50 (2003) nr 1-4:

L. Longobardo - I Padri della Chiesa: Le scelte del Concilio Vaticano II 171-176.

187. ROCZNIKI HUMANISTYCZNE 51 (2003) nr 3-4:

(Nr 3: Filologia klasyczna) A. Eckmann - Obraz Boga w czlowieku wedlug św. Augustyna 75-84; (nr 4: Historia sztuki) B. Iwaszkiewicz-Wronikowska - Pót wieku Katedry Historii Sztuki Starożytnej i Wczesnochrześcijańskiej w Katolickim Uniwersytecie Lubelskim 7-18; M. Malec - Motyw wrzeciona w ikonografii starożytnej $i$ wczesnochrześcijańskiej 53-78; E. Jastrzębowska - Wspólnota za stotem, czyli sceny uczt w późnym antyku 119-134; B. Filarska - B. Iwaszkiewicz Wronikowska - Chrześcijańska topografia Mediolanu w IV wieku 135-169; M. Eysik - Wczesnochrześcijańskie baptysteria Prowansji 171-212; D. Próchniak Wczesnochrześcijański kościót Surb Potos-Petros w Zovuni w Armenii. Problem genezy kościota w typie sali koputowej 213-239; R. Bulas - Ikonografia Daniela między lwami na krzyżach celtyckich 241-263; M. Krasnodębska-D'Aughton Ikony w sztuce rękopisów irlandzkich i anglosaskich (VII-IX wiek) 265-286.

188. ROCZNIKI TEOLOGICZNE 50 (2003) nr 1-9:

(Nr 2: Teologia dogmatyczna) B.J. Huculak - Wczesnochrześcijańska naıḱa o Duchu Świętym w przekazie Dydyma Aleksandryjskiego nazywanego Ślepcem 101-116; (Nr 4: Historia Kościoła) G. Jaśkiewicz - Merytoryczno-formalne aspekty kerygmatu na podstawie mów Grzegorza z Nazjanzu 95-109; J. Pałucki Pismo święte w pasterskiej posłudze Paulina z Noli 139-147; P. Szczur - Wpływ starożytnej myśli greckiej na ksztattowanie się koncepcji roztropności

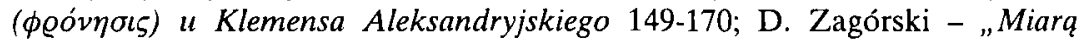
wszystkich rzeczy jest Bóg". Platońska zasada w interpretacji Klemensa Aleksandryjskiego 245-255; M. Ziółkowska - Św. Augustyn prekursorem Soboru $w$ Chalcedonie (451 r.). Zarys doktryny "communicatio idiomatum" $w$ dziele "In Johannis Evangelium Tractatus» CXXIV, 269-283.

189. RÖMISCHE QUARTALSCHRIFT 98 (2003) nr 1-4:

H.J. Tschiedel - Das Fremde als Signum römischer Identität 5-17; J. DreskenWeiland - Fremde in der Bevölkerung des kaiserzeitlichen Rom 18-34; Th. Baumeister - Nordafrikanische Märtyrer in der frühen römischen Heiligenve- 
rehrung 35-46; R. von Haehling - Zwei Fremde in Rom. Das Wunderduell des Petrus mit Simon Magus in den Acta Petri 47-71; E. Dassmann - Ambrosius in Rom 72-86; R. Klein - Zur heidnisch-christlichen Auseinandersetzung in Rom um die Wende vom 4. zum 5. Jahrhundert: Prudentius in Rom 87-111; A.M. Nieddu - Fremde in der Nekropole von S. Paolo fuori le mura; H. Feichtinger - „Doctrine genus haud leve”. Der Exkurs über Weissagung in den "Res gestae» des Ammianus Marcellinus (XXI 1, 6-14), 137-161; B. Bleckmann "Arelate metropolis". Uberlegungen zur Datierung des Konzils von Turin und zur Geschichte Galliens im 5. Jahrhundert 162-173.

190. RUCH BIBLIJNY I LITURGICZNY 56 (2003) nr 1-4:

T. Sinka - Kult relikwii świętych $w$ aspekcie historyczno-liturgicznym 193-200.

191. SACRA DOCTRINA 48 (2003) nr 1-6:

C. Charamsa - Davvero Dio soffre? La Tradizione e l'insegnamento di S. Tommaso, cap. III: La Tradizione patristica sull'impassibilità divina (nr 1) 100-190; cap. IV: La Tradizione del Magistero sull'impassibilità divina (nr 2) 191-214; (nr 5) A. Carpin - Itinerario spirituale isidoriano: dal peccato alla virtù 82-154; A. Carpin - Escatologia in Isidoro di Siviglia 83-175.

192. SACRIS ERUDIRI 42 (2003):

G.W. Lorein - The Antichrist in the Fathers and their Exegetical Basis 5-60; G. Dunn - A survey of Tertullian's soteriology 61-86; Th. Gärtner - Ein christologisches Paradoxon in der Gattungstradition der lateinischen Bibeldichtung (Sedul. carm. pasch. II 54-62), 87-95; E. Rose - Liturgical Latin in the "Missale Gothicum» (Vat. Reg. lat 317). A reconsideration of Christine Mohrmann's approach 97-121; J. Castro Sanchez - Himnos de la Antigua liturgia hispánica. Edición critica, traducción y Fuentes 123-280; B. Janssens - Does the Combination of Maximus" "Ambigua ad Thomam» and «Ambigua ad Iohannem» go back to the Confessor himself? 281-286; E. Mégier - Otto of Freising's revendication of Isaiah as the prophet of Constantine's ,exaltation of the Church" in the context of Christian latin exegesis 287-326; A.J. Forte - Bengt Löfstedts "Fragmente eines Matthäus-Kommentars»: Reflections and Addenda 327-367.

193. SALESIANUM 65 (2003) nr 1-4:

S. Borzì - Sulla datazione del "Contra Hieroclem" di Eusebio di Cesarea 149-160: L. Perrone - „Confessio" e "Narratio". Introduzione al "De catechizandis rudibus» di sant'Agostino 161-172; R. Iacoangeli - Anima ed eternità nel "De Isaac el anima» di sant'Ambrogio 259-300; C. Semeraro - Lettura e interpretazione della pietà popolare. Forme e sviluppi della pietà popolare. La prospettiva storica 447456; L.F. Pizzolato - Il latino e i cristiani. A proposito di una recente raccolta di studi 589-599; G. Bonney - Irenaeus narrates on episode of a public „confession" 757-767; E. Dal Covolo - Il Credo di Nicea. A proposito di un libro recente 769778: C. Semeraro - Biblioteca e bibliografia. Contributo per la storia della conservazione e della catalogazione libraria nel mondo della ricerca 779-800.

194. SALVATORIS MATER 5 (2003) nr 1-4:

(Nr 4) J.J. Janicki - Boże macierzyństwo Najświętszej Maryi Panny w ambrozjańskiej liturgii Adwentu 74-93. 
195. IL SANTO 43 (2003) nr 1-3:

M. Vogrin - Un frammento del «Codex Theodosianus» nella Biblioteca dei frati Minori Conventuali a Ptuj 719-723.

196. SCIENCE ET ESPRIT 55 (2003) nr 1-3:

J. Nelson Novoa - The Appropriation of Jewish Thought by Christianity. The Cases of Philo of Alexandria and Leone Ebreo 285-296.

197. SCRIPTA THEOLOGICA 35 (2003) nr 1-3:

L.F. Mateo-Seco - Notas sobre el lenguaje cristológico de Gregorio de Nisa 89-112; G. Aranda - El libro sagrado en la literatura apocalíptica 319-353; L.F. MateoSeco - Perichóresis y circuminsessio 507-515; B. Częsz - Los efectos de renovación de los estudios patrísticos sobre la pneumatología postconciliar 875-887.

198. LA SCUOLA CATTOLICA 131 (2003) nr 1-4:

F. Braschi - La 14 ${ }^{\text {ma }}$ Conferenza patristica internazionale a Oxford 655-661.

199. SEMINARE 19 (2003):

T. Kolosowski - Święty Jan Chryzostom. Portret kaznodziei - duszpasterza 397-409.

200. SETTE RELIGIONI 13 (2003) nr 33-36:

(Nr 34) S. Ticozzi - Le tradizioni religiose minori in China. Le religioni persiane: Zoroastrismo e Manicheismo 21-29; La Chiesa cristiana siro-orientale 30-39; (nr 36) F. Poli - Il Parsismo - un'antica religione iranica. Il Mazdeismo e le grandi dinastie iraniche 34-41.

201. ST. VLADIMIR'S THEOLOGICAL QUARTERLY 47 (2003) nr 1:

A.F.C. Webster - Justifiable War as a "Lesser Good" in Eastern Orthodox Moral Tradition 3-58.

202. STUDIA ANSELMIANA (2003) t. 137 i 138:

(T. 138) J. Driscoll - Theology at the Eucharistic Table. Master Themes in the Theological Tradition 1-251.

203. STUDIA BOBOLANUM (2003) nr 1-4:

$(\mathrm{Nr}$ 1) R. Zarzeczny - Legenda grecka o męczeństwie proroka Izajasza (CLApNT 316; BHG 958), 179-191; (nr 3) H. Pietras - Do petni życia w Duchu Świętym. Orygenes «O zasadach»I 3, 8, 43-51.

204. STUDIA CATHOLICA PODOLIAE 2 (2003):

R. Kantor - La evangelizacion en casas en la Iglesia primitiva 391-424;

$\mathrm{K}$. Tyburowski - I diritti del diavolo sull'umanità peccatrice nella teologia dell'Ambrosiaster 489-501.

205. STUDIA DIECEZJI RADOMSKIEJ 5 (2003):

S. Jaśkiewicz - „Ascensus ad Deum” w «Wyznaniach» św. Augustyna 53-56;

S. Laskowski - Życie afektywne czlowieka $w$ raju $i$ w szczessliwości wiecznej $w$ świetle nauki św. Augustyna 635-648.

206. STUDIA GNESNENSIA 17 (2003):

B. Czyżewski - Postawa św. Cypriana wobec apostatów na podstawie jego "Listów» 185-202.

207. STUDIA LAURENTIANA 3 (2003) nr 1-2:

(Nr 1) D. Kasprzak - Starożytne chrześcijaństwo w mieście 5-27. 
208. STUDIA LITURGICA 33 (2003) nr 1-2:

A. Stewart-Sykes - Prayer Five Times in the Day and at Midnight: Two Apostolic Customs! 1-19; M. Peppard - Musical Instruments and Jewish-Christian

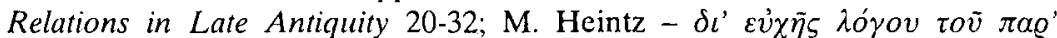
av่toũ (Justin, Apology I 66, 2): Cuming and Gelston Revisited 33-36; M.P. Foley - Bethrothals: Their Past, Present, and Future 37-61; P. Galadza - Lost and Displaced Elements of the Byzantine Funeral Rites: Toward a Pastoral Reappropriation 62-74; Th.J. Talley - Further Light on the Quatrodeciman Pascha and the Date of the Annunciation 151-158; M.F. Connell - „Just as on Easter Sunday": On the Feast of the Presentation of the Lord 159-174; S. Jones - The Womb and the Spirit in the Baptismal Writings of Ephrem the Syrian 175-193.

209. STUDIA MISSIONALIA 52 (2003):

G. Kaniarakath - Apostle Thomas and the mission to the nations 365-389.

210. STUDIA MONASTICA 45 (2003) nr 1-2:

J. Driscoll - The "Circle of Evagrius" then and now 7-18; A. Linage Conde - En el presentimiento de Europa: san Martín de Tours entre el monasterio y la diócesis 19-51; S. Salvestroni - Fedor Dostoevskij, Silvano dell'Athos, Simeone il Nuovo Teologo e la volontaria discesa agli inferi 61-71; A. De Vogüé - Le rôle de l'abbé selon la Règle de saint Benoît dans une culture qui change 421-432.

211. STUDIA PŁOCKIE 31 (2003):

W. Turek - Dlaczego studiować Ojców Kościota? Niektóre wskazania Magisterium Kościoła 15-26.

212. STUDIA REDEMPTORYSTOWSKIE (2003) nr 1:

K.W. Gródek - Bóstwo i boskość w poczq̨tkach myśli greckiej 87-96; M. Raczkiewicz - Święty Efrem - syryjski poeta tajemnic Pana 135-143; B. Cison - Prawo „do azyli", czy prawo „o azyl". Instytucja azylu w zarysie 215-160.

213. STUDIA SANDOMIERSKIE 10 (2003):

K. Tyburowski - Przedmiot grzechu Adama w myśli Ambrozjastra na tle wspótczesnego mu "status quaestionis" 239-251.

214. STUDIA TEOLOGICZNE BIAŁYSTOK - DROHICZYN - ŁOMŻA 21 (2003):

M. Skierkowski - Pierwszy pośród sług jedności. 25 argumentów na prymat Biskupa Rzymu 363-389.

215. STUDIA THEOLOGICA (CZ) 5 (2003) nr 11-14:

(Nr 12) F. Kunetka - Chrám jako „domus ecclesiae"68-74.

216. STUDIA THEOLOGICA (NOR) 57 (2003) nr 1-2:

B.A. Pearson - Cracking a Conundrum: Christian Origins in Egypt 61-75.

217. STUDIA THEOLOGICA VARSAVIENSIA 41 (2003) nr 1-2:

(Nr 1) T. Stępień - Neoplatoniskie źródła problemu pochodzenia Osób Boskich 41-58; (nr 2) S. Dziekoński - Sztuka sakralna jako temat katechetyczny 103-119.

218. STUDIA WARMIŃSKIE 40 (2003):

E. Weber - Źródta patrystyczne „O jasnym a szczyrym Stowie Bożym” Stanistawa Hozjusza 253-276.

219. STUDIA WŁOCŁAWSKIE 6 (2003): 
T. Kaczmarek - Zto o charakterze osobowym - szatan w refleksji teologicznej i doświadczeniu Kościoła 241-154.

220. ŚLĄSKIE STUDIA HISTORYCZNO-TEOLOGICZNE 36 (2003) nr 1-2:

(Nr 1) R. Szmurło - Szenute z Atripe w świetle „Listów $i$ Kazañ" archimandryty Bezy 116-126; (nr 2) Z. Małecki - Naród żydowski i jego Święte Pisma w Biblii chrześcijańskiej. Egzegeza w Qumran 360-366; L. Misiarczyk - Apokatástasis zrealizowana, aktualna i przyszła w tradycji biblijnej i patrystycznej przed Orygenesem 459-476; J. Słomka - Teologiczne podstawy egzegezy Orygenesa i jej aktualność 477-489; W. Myszor - Dialog Zbawcy. Wstęp i tłumaczenie utworu z Biblioteki z Nag Hammadi (Nag Hammadi Codex III 3), 490-503; R. Szmurło - Męczeństwo i śmierć Maniego (Psalm Bema CCXXVI). Wstęp, komentarz i thumaczenie $\mathrm{z}$ języka koptyjskiego 504-508.

221. TEOLOGIA I CZEOWIEK (2003) nr 1-2:

(Nr 2) W. Niedźwiecki - Bibliografia do studium liturgiki 183-180.

222. TEOLOGA ESPIRITUAL 47 (2003) nr 141:

(Nr 141) J.A. Galindo Rodrigo - La ascesis cristiana en la espiritualidad de San Agustin 187-222.

223. TEOLOGIA POLITYCZNA (2003/2004) nr 1:

W. Myszor - Między ortodoksja i herezja 133-139; L. Mateja - Sprawiedliwość i mitosierdzie w starożytności. Porównanie myśli Seneki i Tertuliana 140-147; M.A. Cichocki - Wieczny pokój u Augustyna. Teologia polityczna wobec filozofii politycznej 185-193;

224. TEOLOGIA Y VIDA 44 (2003) nr 1-3:

R. Feldmann - Mesianismo y milenarismo desole la perspectiva judaíca 155-166;

C. Pierantoni - El milenio en la patrística: alternativa entre interpretación literal e interpretación alegórica 184-195; R. Rusconi - La historia del fin: cristianismo y millenarismo 209-220.

225. TERESIANUM 54 (2003) nr 1-2:

A. Mitescu - La cristianizzazione dei Goti, specchio del confronto tra gli Arianie i Niceni (IV-VI secolo) 197-229; Ch Göbel - Wahrheit und Methode. Platonische Dialektik und Evagrische Seelenführung 231-260.

226. TERMINUS 5 (2003) z. 1:

K. Bielawski - Pojęcie "theologia" $i$,theologos" $w$ greckiej tradycji literackiej 81-105.

227. QEOLOGIA 75 (2003) nr 1-2:

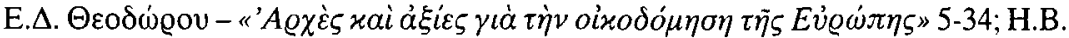

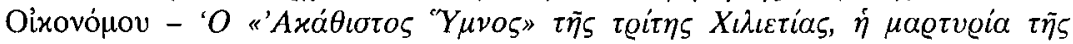

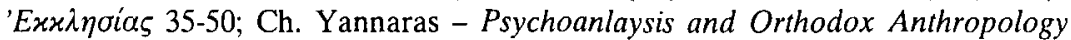

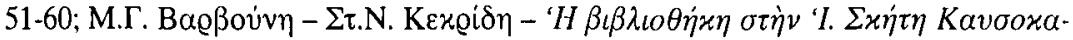

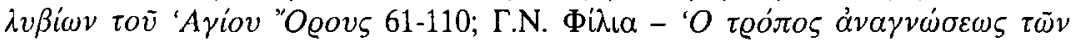

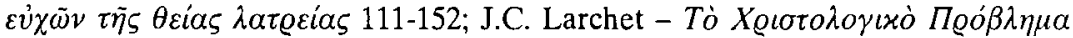

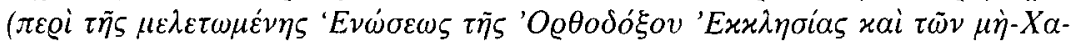

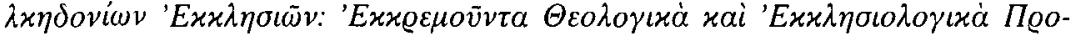
$\beta \lambda \dot{\eta} \mu \alpha \tau \alpha$ 199-234; 633-670; M. Marioras - L'institution du Synode de Province 


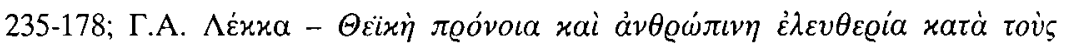

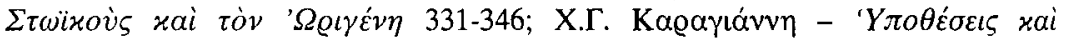

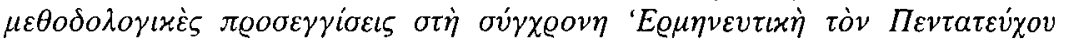

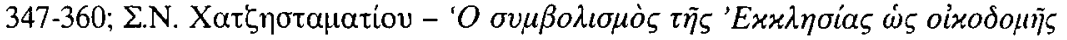

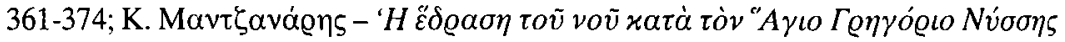

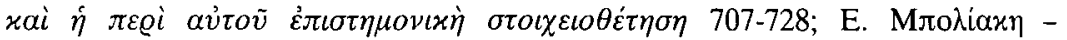

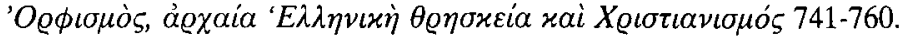

228. THEOLOGICA 38 (2003) nr 1-2:

R. Amaral - O Ideal Eremítico no Monacato de São Frutuoso de Braga 107-117. 229. THEOLOGICAL STUDIES 64 (2003) nr 1-4:

J.F. Baldovin - Hippolytus and the "Apostolic Tradition»: Recent Research and Commentary 520-542; S. Beggiani - The Typological Approach of Syriac sacramental Theology 543-557; N Ormerod - Augustine's «De Trinitate» and Lonergan's Realms of Meaning 773-794; T. Matovina - Guadelupe at Calvary: Patristic Theology in Miguel Sánchez's "Imagen de la Virgen María" (1648) 795-811.

230. THEOLOGIE UND GLAUBE 93 (2003) nr 1-4:

E. Feldmann - Einfïhrung in Augustins «Confessiones» - ein Fragment 134-161; C.P. Mayer - Augustinus - Doctor Gratiae. Das Werden der augustinischen Gnadenlehre von den Fruhschriften bis zur Abfassung der "Confessiones" 163-175; N. Fischer - Freiheit und Gnade. Augustins Weg zur Annahme der Freiheit des Willens als Vorspiel und bleibende Voraussetzung seiner Gnadenlehre 176-195; D. Hattrup - Die Befreiung aus der Sorge - Augustinus liest den Psalm 4, 196-207; A. Raffelt - „Profectus sum abs te in regionem longinquam” ("Conf.» 4, 30). Das Gleichnis vom "verlorenen Sohn" in den "Confessiones" Aurelius Augustinus 208-222; P. van Beek - Das Willensdrama der Befreiung. Anmerkungen zur Kehltüre von «Confessiones» 8, 223-239; L. Seelbach - Psychoanalitische Deutungsversuche zur Persönlichkeit Augustins - Beispiele und Anfragen 240-260.

231. THEOLOGIE UND PHILOSOPHIE 78 (2003) nr 1-4:

H.J. Sieben - „Unsere Sache ist es nicht, schöne Reden zu halten, sondern Taten vorzulegen...". Sexualethik bei Platon («Nomoi») und in der frühen Christenzeit (2. - 3. Jahrhundert) 481-508.

232. THEOLOGISCHE QUARTALSCHRIFT 183 (2003) nr 1.4:

H.J. Vogt - Kollegialität in vorchristlichem und christlichem Altertum. Versuch eines Überblick 281-296; H.R. Seeliger - Litteratulus christianus. Beobachtungen und Bemerkungen zum Bildungsgrad der antiken Christen 297-312.

233. THEOLOGISCHE ZEITSCHRIFT 59 (2003) nr 1-4:

E. Friedheim - Politique et Rabbinisme en Palestine Romaine. Opposition, approbation et réalités historiques 97-112; U. Mell - Die Entstehung der christlichen Zeit 205-221.

234. THEOLOGY TODAY 60 (2003) nr 1-4:

I.A. McFarland - Developing an Apophatic Chrislocentrism: Lessons from Maximus the Confessor 200-214.

235. THÉOPHILYON 8 (2003) nr 1-2:

D. Bcrtrand - Le creuset alexandrin du discernement des esprits 487-516. 
236. THEOTOKOS 11 (2003) nr 1:

M.G.Mara - Il quarto secolo: quadro politico e culturale 17-40; L. Gambero - La Madre di Dio nella cristologia di Basilio di Cesarea 41-72; F. Trisoglio - La nascita di Cristo e la profezia di Simeone in Basilio di Cesarea 73-89; F. Trisoglio - La Madre di Dio in Gregorio di Nazianzo 91-124; E. Giannarelli-Gregorio di Nissa: fili mariani 125-143; A.M. Martone Berruto - Maria nel Montanismo 145154; D. Mazzoleni - Riferimenti a Maria nell'epigrafia cristiana dei primi secoli 155-176; M. Candidi - I pagani di Harran (sec. V-XI d.C.) 177-192.

237. THOMIST 67 (2003) nr 1-4:

Th.M. Osborne - The Augustinianism of Thomas Aquinas's Moral Theory 279-305. 238. TYNDALE BULLETIN 54 (2003) nr 1-2:

(Nr 1) M. Wilson - Cilicia: The First Christian Churches in Anatolia 15-30;

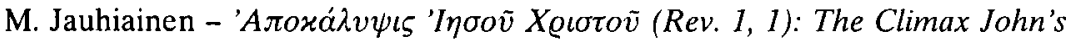
Prophecy? 99-117; (nr 2) J. Henžel - When Conversion is Joy and Death Victory: Historical Foundations of the Doctrine of Perseverance 123-148.

239. UNA SANCTA 58 (2003) nr 1-4:

V. Karayiannis - Der Segen in der orthodoxen Kirche 175-187; I. Totzke - Die Botschaft der Bibel in den Christushymnen der Ostkirche 288-309.

240. VERBUM VITAE (2003) nr 3-4:

(Nr 3) L. Mateja - Mitosierdzie w kontekście dobroci i cierpliwości w ujęciu Tertuliana 203-212; M. Szram - „Słodkie imię miłosierdzia”. Cezariańska koncepcja dialogu miłosierdzia niebiańskiego z ziemskim 213-232; (nr 4) J. Słomka - Starotestamentalne przymierza $w$ interpretacji Orygenesa 213-226; A. Uciecha - Idea przymierza (qyāmā) w "Mowach» Afrahata 227-243; M. Rosik - Zapowiedź nowego przymierza (Jr 31, 31-34) w «Enarrationes in Psalmos» św. Augustyna 245-265.

241. VERITAS 48 (2003) nr 1-4:

B. Silva Santos - Platonismo e cristianismo: irreconciabilidade radical ou elementos comuns? 323-236; A.J. da Silva - A integração entre razão e fé em Agostinho 337-342; R. Saraiva Kahlmeyer-Mertens - Memória e confissão como exercício prático do conhecimento da verdade de Deus no pensamento de Agostinho 343-350; J. Renivaldo Rufino-Passado, presente e futuro: o tempo da consciência e a consciência do tempo no pensamento de Agostinho 351-360; A. Fornari - San Agustín: la alternativa del deseo y el origen de la violencia 361-374; M.R. Nunes Costa - Evolução da doutrina ético-moral agostiniana em relação à sexualidade 375-390.

242. VERKÜNDIGUNG UND FORSCHUNG 48 (2003) nr 1-2:

(Nr 2) R. von Bendemann - „Theologie des Neuen Testaments” oder ,Religionsgeschichte des Frïhchristentums"? 3-28; B. Wander - Auseinandersetzungen zwischen antikem Judentum und frühem Christentum 29-43; U.U. Kaiser Neuere Gnosisforschung 44-64; R. Staats - Ignatius und der Frühkatholizismus Neues zu einem alte Thema 80-92.

243. VETERA CHRISTIANORUM 40 (2003) nr 1-2:

I. Aulisa - .Papisci et Philonis Iudaeorum cum monacheo colloquium”; note per una ricostruzione del confronto tra gitudei e cristiani in epoca altomedievale 17-41; 
L. Carnevale - Totila come „perfidus rex" tra storia e agiografia 43-69; A.E. Felle - Epigrafia e Sacra Scrittura: un'iscrizione nubiana scomparsa (CIG, IV 8888). 71-91; G. Nigro - Il Molise paleocristiano dalle origini a Gregorio Magno 93-116; M. Simonetti - L'origine dell'esegesi cristiana in Occidente 117-131; M. Veronese - Le citazioni del «De Trinitate» di Ilario nella raccolta attribuita a Priscilliano 133 157; P. Ressa - Note al testo del "Contro Celso» 159-166; L. Viscido - Per una plausibile interpretazione di „sint haec divina perpetua" in Cassiod., Var. 13, 8 , 167-168; M. Simonctti - Presenza di Paolo nella cristologia patristica 191-205; G. Otranto - Da Giuliano di Eclano ad Eugippio: la campania tra eresia e ortodossia 207-224; G. Andenna - Di un nuovo centro di culto micaelico nell'Italia settentrionale: "Collegium qui dicitur Langobardorum” 225-249; F. Bisconti - Variazioni sul tema della "Traditio legis”. Vecchie e nuove acquisizioni 251-270; A. Campione - Note per la ricostruzione del dossier agiografico di Secondino vescovo di Aecae 271-292; M. Donnini - Intorno ad un'ascendenza di Cassiodoro nella «Vita s. Athanasii” (BHL 735), 293-299; R. Giordani - „Et sepultus est iuxta corpus beati Petri in Vaticano". Qualche considerazione sul problema delle sepolture dei papi nell'antichità 301-317; V. Novembri - Due epistole, una „consolatio”: Basilio di Cesarea a Nettario e alla sua consorte (Ep. 5 e 6), 319-337; I. Ramelli - I parenti terreni di Gesiu. Note in margine a una discussa scoperta epigrafica 339-355.

244. VETUS TESTAMENTUM 53 (2003) nr 1-4:

M. Kraus - Hebraisms in the Old Latin version of the Bible 487-513.

245. VIDA SOBRENATURAL 83 (2003) nr 625-630:

M.Á. del Río - La lectura patrística en el oficio divino 269-275.

246. VIGILIAE CHRISTIANAE 57 (2003) nr 1-4:

A. Hofer - The old man as Christ in Justin's «Dialogue with Trypho» 1-21: P.I. Kaufman - Patience and/or politics: Augustine and the crisis at Calama 408-409, 22-35; Gert Partoens - Acts 27-28 in the Preface to Prudentius's first liber "Contra Symmachum» 36-61; N.I. Fredrikson - La douceur et l'amertume dans le langage spirituel des saveurs 62-93; Ch.A. Gieschen - The divine name in Ante-nicene Christology 115-158; J. Joosten - The dura parchment and the "Diatessaron" 159-175; U.B. Schmid - In search of Tatian's "Diatessaron" in the West 176-199; B. Bitton-Ashkelony - Demons and prayers: spiritual exercises in the monastic community of Gaza in the fifth and sixth centuries 200-221; P. Luomanen - Where did another rich man come from? The Jewish-Christian profile of the story about a rich man in the "Gospel of the Hebrews" (Origen, "Comm. in Matth.» 15, 14), 243-275; F.B.A. Asiedu - Following the example of a woman: Augustine's conversion to Christianity in 386, 276-306; A.D. De Conick - The great mystery of marriage sex and conception in ancient Valentinian traditions 307-342; R. van den Brock - Gospel tradition and salvation in Itustin the Gnostic 363-388; C. Scholten - Ein unerkannter Quaestioneskommentar («Exc. Theod.» 4f) und die Deutung der Verklärung Christi in frïhchristlichen Texten 389-410; L. Painchaud - L'utilisation des paraboles dans l'«Interprétation de la gnose» (NH XI l), 411-436; W. Löhr - Valentinian variations on $L k 12,8-9 / \mathrm{Mt} 10,32,437-455$. 
247. VITA MONASTICA 57 (2003) nr 223-225:

(Nr 225) G.J. Gargano - Commento ad un'omelia di Gregorio Magno su Ezechiele 1, 19-21, 40-47.

248. VIVENS HOMO 14 (2003) nr 1-2:

F. Coduti - Gli "Epitaffi su se stesso» di san Gregorio Nazianzeno: teologia e poesia delle morte 43-72.

249. W DRODZE (2003) nr 1-12:

(Nr 1) K. Najman - Świattość świata u Ojców Kościota 40-42; T. Jaklewicz Świattość świata w tradycji wschodnich Kościotów 42-44; (nr 3) M. de DreuilleKto nie chce pracować - jak pracowali mnisi, tłum. M. Żurowska 43-51.

250. WARSZAWSKIE STUDIA TEOLOGICZNE 16 (2003):

D. De Formigny - Paulin de Pella: Euchristicos 85-100; Dzieje Piotra Apostota i Szymona, thum. Z. Izydorczyk - M. Bielewicz, oprac. Z. Izydorczyk 101-150.

251. THE WESTMINSTER THEOLOGICAL JOURNAL 65 (2003) nr 1-2:

L.C. Sibley - Late Have I Loved You: Augustinian Spirituality in Book 10 of the "Confessions» 69-81; P.H.R. van Houwelingen - The Departure of Christians from Jerusalem to Pella 181-200.

252. WORSHIP 77 (2003) nr 1-6:

P. Bradshaw - Cathedral and Monastic: What's in a Name? 341-353; R.F. Taft Mass Without the Consecration? The Historic Agreement on the Eucharist between the Catholic Church and the Assyrian Church of the East Promulgated 26 October 2001, 482-509.

253. WORT UND DIENST 27 (2003):

U. Schmid - Die Buchwerdung des Neuen Testaments. Über den Zusammenhang von Textgeschichte und Kanonsgeschichte 217-232; K. Bracht - Der bedürfnislose Gott. Zum antiken Hintergrund einer Gottesbezeichnung bei Methodius von Olympus 233-247.

254. Z BADAŃ NAD BIBLIA (2003) nr 6-7:

(Nr 6) P. Fedor - Horyzonty biblijne w grekokatolickiej liturgii św. Jana Ztotoustego 149-159; ( $\mathrm{nr} 7$ ) A. Tyrol - Alegorická relektúra starozákonných textov v kresianských pismach 33-42.

255. ZAMOJSKI INFORMATOR DIECEZJALNY 12 (2003) nr 1-4:

J. Lekan - Komunia św. pod dwiema postaciami (przyczynek historyczno-dogmatyczny) 80-94.

256. ZEITSCHRIFT FÜR ANTIKES CHRISTENTUM 7 (2003) nr 1-2:

H. Förster - „Ich habe dich dem Johannes gegeben, den ich liebe”. Edition von P. Vindob. K. 2644, 3-13; Ch. Auffarth - Die frühen Christentümer als Lokale Religion 14-26; G.O. Kirner - Apostolat und Patronage (II). Darstellungsteil: Weisheit, Rhetorik und Ruhm im Konflikt um die apostolische Praxis des Paulus in der frühchristlichen Gemeinde Korinth (1Kor 1-4 u. 9; 2Kor 10-13), 27-72; J. Zachhuber - Nochmals: Der „38. Brief” des Basilius von Caesarea als Werk des Gregor von Nyssa 73-90; J. Holzhausen - Über den Titel von Nag Hammadi Codex I 3, 91-98; Th.C.K. Ferguson - The Past Is Prologue: Origenism in Book $X$ of the "Ecclesiastical History» 99-112; Ch. Schubert - Sulpicius Severus als 
Satiriker? Text, Übersetzung und Interpretationsversuch zu (Ps.-) Sulp. Sev., "Ep.» 3, 113-139; G.D. Dunn - „Probabimus venisse eum iam”. The Fulfilment of Daniel Prophetic Time-Frame in Tertullian's «Adversus Iudaeos» 140-155; P. Lampe - Die 2002-Kampagne des archäologischen Phrygien-Surveys der Universität Heidelberg. Ein kurzer Vorausbericht 156-159; (nr 2) Th.J. Kraus Petrus und das Ostrakon "van Haelst" 741 - einige klärende Anmerkungen 203211; A. Coşkun - Die Programmgedichte des Prudentius: „praefatio” und „epilogus” 212-136; M. Meier - Die Translatio des Christusbildes von Kamulianoi und der Kreuzreliquie von Apameia nach Konstantinopel unter Justin II. Ein übersehens Datierungsproblem 237-250; M. de Groote - Die Literatur der Kirchenväter im Apokalypsekommentar des Oecumenius 251-262; S. Elm - Historiographic Identities: Julian, Gregory of Nazianzus, and the Forging of Orthodoxy 265-280; L. Lugaresi - Ambivalenze della rappresentazione. Riflessioni patristiche su riti e spettacoli 281-309; L. Perrone - Die "Verfassung der Juden". Das biblische Judentum als politisches Modell in Origenes" "Contra Celsum» 310-328; M. Slusser - The martyrdom of Lucian of Antioch 329-337; Ch. Schubert - ,... nihil difficilius quam hominis interiora comprehendere". $Z u$ einem bisher nicht identifizierten Zitat bei Ambr., Noe 1, 1, 328-242; J.B. Bauer - Wurde Eusebs Psalmkommentar zweimal übersetzt? 343-345.

257. ZEITSCHRIFT FÜR DIE NEUTESTAMENTLICHE WISSENSCHAFT 94 (2003) nr 1-4:

J.R. Levison - The Primacy of Pain and Disease in the Greek «Life of Adam and Eve» 1-16; J. Frei - Die Scholien nach dem ,jüdischen Evangelium" und das sogenannte Nazoräerevangelium 122-137.

258. ZEITSCHRIFT FÜR RELIGIONS- UND GEISTESGESCHICHTE 55 (2003) nr 1-4:

M. Knüppel - Bemerkungen zum „uigurischen” Manichäismus (Konferenzbericht) 272-278.

259. ZESZYTY HISTORYCZNO-TEOLOGICZNE 9 (2003) nr 9:

A. Błyszcz - La struttura ontologica dell'essere razionale e il suo destino definitivo nel terzo libro di «De principiis» di Origene 114-181.

260. ZESZYTY NAUKOWE AKADEMII POLONIJNEJ W CZESTOCHOWIE - PRACE WYDZIAŁU ADMINISTRACYJNO-PRAWNEGO (2003) z. 1:

B. Degórski - Stosunek cesarzy Sewerów do chrześcijan 261-274.

261. ZESZYTY TEOLOGICZNE. FOLIA THEOLOGICA 11 (2002) nr 1-2:

(Nr 2) W. Zatorski - Benedyktyńska filozofia pracy 6-11

262. ŻYCIE DUCHOWE (2003) nr 33-36:

(Nr 34) A. Grün - Przewodnik po duchowości Ojców pustyni, thum. A. Porębski 151-153, (nr 35) W. Turek - Scandalum crucis. Kilka refleksji św. Hilarego $z$ Poitiers 101-105. 